\title{
'THE COUNTRY IS LARGE, AND BEAUTIFUL AND HAPPY.' \\ LELIO PECCI'S TRAVEL JOURNAL OF HIS \\ 1549 MisSION TO FlaNDERS
}

\section{ELENA BRIZIO}

\begin{abstract}
Summary: Lelio Pecci's travel journal for his mission to Emperor Charles $\mathrm{V}$ in Flanders offers modern readers a layman's description of a large section of Europe (from northern Italy to France, Flanders, Germany, and Austria), as well as a priviledged view into the mind of a learned man from a small, but cultured city in Italy. This article briefly contextualizes Pecci's journal in the political situation of Siena in mid-century, presents current biographical information on Lelio Pecci, and discusses some of the most salient aspects of the travel journal. It then provides readers with an appendix containing an annotated transcription of the journal based on its only extant manuscript copy.
\end{abstract}

On 6 September 1549, Lelio Pecci and Alessandro Guglielmi left Siena with an extremely important assignment: to visit Emperor Charles $\mathrm{V}$ in Flanders and try to convince him not to build a fortress in Siena. The idea of erecting a fortress just outside the ancient city walls had ostensibly been advanced as a way to keep the peace in the city-the Spanish garrison it would house was meant to help "pacify" the turbulent political factions in town. The Sienese, however, did not see it this way and viewed the project as, among other things, an expression of lack of trust on the part of the emperor for his loyal, pro-Ghibelline and pro-imperial subjects. To resolve the situation, the Sienese government elected to send two envoys to the emperor to plead the Sienese case in the hope of changing the emperor's mind and thus bringing to a halt the planned construction of the fortress. One of these envoys was Lelio Pecci, a famed and respected jurist in town. The travel journal Pecci kept during his eleven-months journey through northern Italy, France, Flanders, Germany, Austria, and then back again into Italy is not only a record of that mission, but also a lively depiction of a significant swat of Europe in mid-century. It is also a revealing personal document that offers modern scholars and readers a point of entry and a priviledged insight into the mind and eye of a learned, intelligent man from a small, but cultured city as he ventured out into the larger European tableau and came face to face with a variety of cultural, linguistic, religious, and even geographical novelties. But first we need to set the scene in Siena. 


\section{The Political Situaton in Siena}

After the death of Pandolfo "the Magnificent" Petrucci-the only lord Siena had ever had-in 1512, the city had gradually become more and more confused politically, economically, and socially. The Petrucci belonged to the Monte (or faction) dei Nove, the richest and most influential group. The Noveschi viewed themselves as the true nobles of the city, even if a Monte dei Gentiluomini, to whom the members of ancient and famous families belonged, did in fact exist. In the troubled political years following the death of Pandolfo the city became of interest to the Florentines, the different popes and their families, and the many lords of central Italy who were looking to establish or expand their own state. The difficult internal administration of the city, which was based on a repubblican system of shared participation in government by four different monti (Nove, Popolo, Riformatori and Gentiluomini) soon led to the ousting of the Monte dei Nove and the exile of many Noveschi.

In late 1529/early 1530, while in Bologna to be crowned emperor, Charles V was visited by different groups of exiled Noveschi who begged him to help them re-enter Siena and participate once again in the government of the city. The exiled Noveschi and the Sienese in general appeared not to be fully aware of the geopolitical role played by their republic on the Italian and European stage: self-absorbed on their own internal discord, they did not realize that the world was moving faster than they were and that the Emperor did not want troubles in Italy, where a variety of other political leaders-King François I of France and Pope Clement VII de' Medici in particular-were trying to expand their influence.

After 1530, an imperial legal representative was sent to help govern the city. He did not participate in government officially, but sought to direct Siena and the Sienese towards a political course that would be in line with Spanish and imperial intentions. In the convulsive years between 1530 and 1547 many Spanish representatives intervened directly in Sienese politics. Don Lope de Soria and Ferrante Gonzaga, both tried to convince the Sienese government to readmit the exiled Noveschi. They were followed by Alfonso d'Avalos Aquino, Marquis of Vasto, who, in turn, was followed by his brother-in-law Alfonso Piccolomini Todeschini, Count of Amalfi. In 1541, the new Spanish representative was Antoine Perrenot de Granvelle, who re-organized the government without including the formal division in Monti. He was followed by Don Juan de Luna and then, when it seemed that King Henri II of France was starting to plan for new conquests on Italian territory, by Don Diego Hurtado de Mendoza, the Spanish ambassador in Rome. 
Fearing possible French help to the Sienese, Emperor Charles V decided that the only way to keep Siena 'free' was to build a fortress to house a Spanish garrison. In the emperor's view, this would also help to reduce internal squabbles in the city. It is at this point that the Sienese government decided to send an envoy to the emperor to ask him to change his mind.

\section{Lelio Pecci and His Mission to the Emperor in Flanders}

Lelio Pecci was born in Siena in 1510 and died there in 1584 . He was a Novesco, a doctor in utroque iure (that is, in both canon and civil law), a jurist, and a teacher at the university in Siena. In 1539 he married Porzia, the only daughter of the famous jurist Mariano Sozzini the Younger, who some time earlier had taught law at the university in Bologna. ${ }^{1}$ Appointed Uditore di Rota [judge of the Rota] in Bologna, Lelio Pecci declined the office and remained in Siena because one of his brothers had unexpectedly died. As far as we can tell, he had previously left the city only on one occasion, sometime around 1540, in order to go to Rome to buy grain for the Republic. A member of the pro-Spanish faction in the city, Lelio held several important offices from 1537 until the year of his death. Temporarily exiled in 1557 (presumably to his countryside possessions) because of his pro-Medicean views, he was quickly reappointed to the government. He was one of the four Sienese representatives that brought Duke Cosimo I de' Medici the unconditional surrender of the city in 1559 . He welcomed, among others, the first Florentine Governor, Agnolo Niccolini, sent to Siena by Cosimo on 4 April $1558 .^{2}$ Later, he was one of the Sienese government representatives at Cosimo's funeral in $1574 .{ }^{3}$

1 Fumi/Lisini, Genealogia, pp. 54-55.

2 Archivio di Stato di Siena (henceforth ASS), Balìa 169, fol. 42v [4 Apr. 1558] "Elesseno et deputorno per ambasciatori di lor collegio li magnifici messer Lelio Pecci e messer Alisandro [sic] Guglielmi ad andare ad incontrare et honorare il molto magnifico et eccellentissimo signor Governatore nostro in nel suo ritorno alla città menando seco quel numero di giovani a cavallo che si conviene" [They elected and chose as ambassadors of their board the magnificent Lelio Pecci and Alessandro Guglielmi to go meet and honour the most magnificent and excellent Governor of ours in his coming back to the city, bringing with them the suitable number of young knights]. Cosimo had already sent Niccolini to Siena in 1547 as ambassador.

3 ASS, Balìa 179, fol. 129v [4 mag 1574] "si mandino a scontrino [...] i quattro che haveranno più lupini bianchi siano oratori ad andare e trovarsi in Firenze ali 13 del presente [...] per l'esequie del granduca Cosimo I" [let vote and those who 
In 1549, the Sienese government decided to send two ambassadors to Charles V in Flanders begging him not to build a fortress just outside the walls of Siena. The Sienese viewed such a fortress not only as a threat to their republican liberties, but also, and perhaps foremost, as a sign that the emperor did not recognize or appreciate Siena’s long-standing Ghibelline and pro-imperial tradition. A decision to send representatives to the emperor was nothing new in Siena, but this time the Sienese ambassadors had the difficult duty to try to convince Charles $\mathrm{V}$ to change his mind. Problems arose as soon as the Sienese ambassadors arrived in Brussels. Antoine Perrenot de Granvelle, Monseigneur of Arras, ${ }^{4}$ presented to the emperor some apparently anonymous letters that had just arrived from Siena from citizens complaining that they had been denied their right to vote and participate in government. 5 This was a tricky situation-the problem of citizens who had been exiled from the city in 1546, most of whom were from the Monte dei Nove, was one of the worst political dilemmas the Sienese government had to deal with, both inside and outside the city. Not all citizens were against the Spanish administration, and not all citizens were against the Nove (Pecci, for example, was a Novesco), but the situation was not easy to manage.

On this mission Lelio Pecci was accompanied by a secretary and by Alessandro Guglielmi, a Popolare who was later accused of being a double

will receive the most white lupin beans be chosen to go and be in Florence on the 13 of this month at the funeral of Grand Duke Cosimo I"].

4 Antonie Perrenot de Granvelle (1517-1586) was appointed bishop of Arras (hence his title) on 29 November 1538.

5 ASS, Balìa 720, n. 50 [26 Nov. 1549] "Monsignor d'Arras [...] doppo questo ragionamento ci ha domandato chi sieno li cittadini non riseduti in cotesta città, atteso che tiene certe lettere di certe domande che fanno a Sua Maestà et rispostogli noi che non sapevamo chi si fusseno [...] cerchò fra le sue scritture ala presentia nostra in camera sua, et non trovandole disse che ce le manderebbe a l'alloggiamento nostro per il suo segretario, el quale pocho di poi ci ha portato una lettera a Sua Signoria Reverendissima et un memoriale et un'altra lettera aperta a noi medesimi [...] tali humori non possono se non pocho giovare ala resolutione et presta espeditione de le cose" [Monseigneur of Arras [...] after this discussion asked us who are the citizens not allowed to govern the city, since he had some letters with some questions for His Majesty and having answered we did not know who they could be [...] in our presence he looked among his papers in his room and not finding them he told us he would send his secretary to our apartment, who almost immediately brought us a letter to His Reverend Lord, and a note and another letter to ourselves already open [...] these moods cannot help the resolution and quick fulfillment of our business]. 
agent for Don Diego Hurtado de Mendoza. It seems, in fact, that, unknown to Pecci, Guglielmi was secretly instructed by Mendoza to plead for the building of the fortress. The official documentation sent by the two envoys to the Balìa shows that, while both Pecci and Guglielmi were in the presence of Charles V, Guglielmi talked to the emperor about a fortress that should be built along the coast, possibly at Orbetello, and explained that he had brought maps and drawings of what had already been done and was still to be done. The emperor seemed pleased with the news and asked Guglielmi to remind him of the matter and to show him the maps. ${ }^{6}$ Was that a trick on Guglielmi's part to present the emperor with suggestions for the fortress outside Siena? It is possible, but not certain. Clearly something happened and it changed the nature of the mission.

When news of a possible betrayal began to spread, Alessandro Guglielmi was quick to write to the Sienese government detailing his activities and his behaviour so as to clear himself as much as possible of suspicion. He was informed about two specific accusations: the first was that he had apparently negotiated alone, without Lelio Pecci present, and the second was that he had negotiated on matters that were not part of the written instructions given to the two ambassadors (the so called notula). On the first charge, Guglielmi explained: "I never negotiated without Messer Lelio, because we always went everywhere together [...] and Messer Lelio, being a jurist, has always been closer to those we were talking to, and all my words have been heard by him and he had no chance to negotiate without me, and I could not negotiate without him."7 On the second charge, he was even more specific: "About the second [charge], I don't know if the defamation is for me only or for both Messer Lelio and me: in both cases,

6 ASS, Balì 720, n. 50 [26 Nov. 1549] “ [...] et havendoli Alessandro nel parlar suo detto sopra il particular dele fortificationi di mare [sic], come haveva portato le piante et disegni di quel che vi s'era già fatto, et che giudicava che fussi da farvi, [Carlo V] ne mostrò molta sodisfattione, et disse che glielo facessi ricordar perché desiderava vederli" [and after Alessandro had said to the Emperor, in his speech, about the details of the fortifications near the sea, and how he had brought maps and drawings of what has already been done, and what he thought needed to be done, [Charles V] showed great satisfaction, and told him to remind him of the matter, because he wanted to see the drawings and maps].

7 Balìa 722, n. 2 [26 Mar. 1550] "Io non ho mai fuor di messer Lelio perché siamo andati sempre insieme, ne mai è uscito fuor di casa l'un senza l'altro [...] messer Lelio come dottore è stato sempre più vicino a quell con chi s'è negoziato, di sorte che le parole mie sono state tutte benissimo intese da lui et così né esso ha potuto negoziar senza me, né io ho potuto negoziar senza lui". 
I can feel that the malice and the poison are aimed at the same target." 8 Pecci felt compelled to write two letters to the Balì defending Guglielmi and their joint handling of the mission. In the first letter, composed by both but signed only by Pecci, they wrote "We pray you to look out for the defamation that we hear going around there [in Siena] against our Alessandro, because it is all falsity and malice [...] and if Your Lords would not take offence at that, it would be like tying up the hands of your officials, because they would not be able to do their job, considering that backbiters would be more powerful than good actions." 9 The second letter was composed and signed by Pecci alone, who expressed his point of view to the Balì saying: "I repeat to Your Lords that I never knew that Messer Alessandro did this particular thing, because we never left the house without the other, and we never talked to anyone by ourselves: unless you are referring to the fact that while meeting one day in the home of Most Reverend d'Aras, Alessandro approached the Castaldo and told him 'the knight Severino and Fantozo beg you that at least they can come back to the Sienese countryside' [...] and I [Pecci] told him that it was not our mission to beg for private persons, but for the good of everyone." 10 If Pecci and Guglielmi had some difficult times, it does not seem that this prevented them from working together again for the Sienese government on

8 ASS, Balìa 722, n. 2 [26 Mar. 1550] "Quanto ala seconda poi del mio negoziar fuor di notola, io non so se questa calunnia è data a me solo o se l'è data a messer Lelio et a me insieme: et ne l'uno et ne l'altro modo dico che l'è stata la medesima malignità et veleno".

9 ASS, Balìa 722, n. 6 [30 Mar. 1550] "Preghianle oltre a questo che voglino ricercare et ritrovare la calunnia che si intende essere stata cavata fuore costà contra di Alessandro nostro, perché è tutta falsità e malignità [...] che quando Vostre Signorie non se ne risentissero, sarebbe come un leghar le mani a ministri loro, acciò non sapesseno ne potesseno più servirle, vedendo che gl'havessino a poter più le male lingue che le buone opere".

10 ASS, Balìa 722, n. 7 [31 Mar. 1550] "Replico a Vostre Signorie Illustrissime ch'io non ho mai saputo che messer Alessandro habbia fatto tal cosa, perché mai qual sia di noi ha messo piede fuor di casa senza l'altro, ne anco dove siamo stati qual sia di noi ha parlato senza l'altro, se già non fusse voluto intendere perché ritrovandoci noi un giorno in casa del Reverendissimo d'Aras, messer Alessandro s'accostò al Castaldo et li disse 'Il cavaliere Severino et Fantozo vi si raccomandano che almeno possino tornare nel contado di Siena' [...] al che io risposi che questa non era nostra commissione di fare per particolari, ma si bene generalmente per tutti”. Both Giovan Francesco Severini and Giovan Battista Fantozzi, belonging to the Popolari, were exiled in 1547 following another aborted attempt to let the Nove re-enter the city. 
other occasions. In fact, in 1558 they were both chosen to welcome Governor Niccolini to Siena.

\section{The Travel Journal}

The original, and presumably autograph copy of Lelio Pecci's journal of his travel to Flanders has not yet been located. If it has survived to the present day, it is probably to be found in the Piccolomini papers in the Archivio di Stato di Siena, but a continuing search for it has not yet produced any positive results. What has survived, instead, is a copy of the original entitled "Itinerario di Lelio Pecci dottore in Fiandra, oratore a Carlo Quinto imperatore 1549 155" [sic] that is housed at the Biblioteca Comunale di Siena (MS C.IV.24, fols. 195v-214r). The final lines of the transcription report that "the above itinerary by Messer Lelio Pecci was copied from his own original extant [in the library of] the heir of the late Signor Francesco Piccolomini." 11 The currently extant manuscript is thus, clearly, a copy of the original.

A printed edition of the journal was published in 1880 in the volume Genealogia dei conti Pecci signori di Argiano, but it contains so many infelicities and inaccuracies that it is not a reliable source for scholarly research. The text I present as an appendix to this note is thus based on the manuscript copy. Punctuation and capitalization have been adapted to modern use. Whenever possible people and places have been identified (in modern style). Unusual or difficult terms have been thoroughly checked in etymological dictionaries. Sentences have been left as they appear in the manuscript without any attempt to modernize their structure because, often, it is difficult to determine exactly where a sentence should end. Variants with the 1880 printed edition are indicated in the footnotes, where ' $a$ ' and ' $b$ ' are used to indicate the colums present in that edition.

The manuscript is 20 folios long and deals only with the journey itself. It does not provide any political information on the mission-such information would have been sent directly to the Balia in Siena as official correspondence and would have been highly inappropriate for a travel journal.

The journal reveals that Pecci was very precise and detailed in recording distances (and the different number of the miles in a lega in the various territories he crossed), as well as the exchange rate of coins used in different cities. The places and the names of moneychangers (usually Lucchese merchants), their Sienese counterparts, and the exchange rates and interest

11 "Copiato il sopradetto itinerario di m. Lelio Pecci dal suo proprio originale esistente appresso gl'eredi del già signor Francesco Piccolomini." BCS, MS C.IV.24, fol. 214 r. 
charged current at that time are also recorded. This was important information because Pecci and Guglielmi, though official ambassadors of the Republic, were in fact paying for the journey out of their own pocket because the official provisions for their wages were very difficult to be paid in foreign countries and were always late in arriving. They were thus obliged to have recourse to moneychangers or merchants whom they or their Sienese colleagues knew, trusted, or were related to. The difficulties the two ambassadors encountered in funding their mission and in receiving financial support from the government in Siena is clearly evident in Pecci's official missives to the Balìa. In many letters, Pecci and Guglielmi complain that they have no money to live on or to to pay for their court expenses and were thus obliged to borrow money at high interest.

[...] after our arrival [in Speyer] considering the difficulties in negotiating $[\ldots]$ and the distance of the journey $[\ldots]$ we pray you to take into account that when you will receive our letters it will already be four months since our departure and that we have already given to our secretary 50 scudi from the provisions for our fifth month, and about 70 or more have been paid in tips and extraordinary expenses between here and Milan, and another 80 or 100 scudi will be paid in Christmas tips, at which time we will already be broke. ${ }^{12}$

[...] because we have already finished the money, because tips have depleted our finances, we pray you to supply us as soon as possible for all the time you calculate we will be staying [...] because here we spend all we have and we will spend more of our own money to honor you, and if we had goods or credit here we would not disturb you as much as we do. ${ }^{13}$

12 ASS, Balìa 720, n. 61 [16 Dec. 1549] "Et doppo l'arrivo [a Spira] considerando ala difficultà che ci è del neghotiare [...] et di poi la distantia del viaggio [...] pertanto le preghiamo voglino considerare quando riceveranno queste nostre che già saranno un quattro mesi dala nostra partita, et che la provisione del quinto mese già n'haviam dato al segretario nostro scudi 50 , et circa scudi 70 più ne sono andati in mancie e straordinari fra qui e Milano, et scudi 80 o 100 n'andaranno più nele mancie a Natale, a tal che a quel tempo restaremo già al verde."

13 ASS, Balìa 720, n. 95 [30 Dec. 1549] "Et perché siamo al ultimo de denari, atteso che già le mancie ci hanno finito di consumare la nostra provisione, le preghiamo voglino provvederci quanto più presto per quel tempo che possano considerare che potiamo stare [...] perché qua si spende quel che le ci danno et ancora ci spendaremo del nostro per honorarle, et se qua havessemo o robba o credito non le sollecitaremo tanto quanto faciamo." 
Money was also a problem when trying to return home because the ambassadors were obliged to follow the imperial court in its displacements and thus expenses accumulated quickly, as reported in several letters sent in March and April 1550.

[...] here, in order no to fail in public honor, and in our own in particular, each of us has borrowed 100 scudi while waiting for our salary from Your Lords in order to pay them back, and so we pray you [...] not to forget to send it immediately by your leave, so that we can pay our debts with one [salary] and come back home with the other [... ${ }^{14}$

[...] we have waited until now for some financial provisions from Your Lords and we are still waiting because we cannot do anything any more, if we do not receive your pay order tomorrow or the day after tomorrow, we will be compelled to go to Antwerp for a night and seek to borrow [money] there, because here it is not possible, even if it will be with shame and poor reputation, public and our, we will be excused by the fact that we waited as much as possible, having lived many days on borrowed money and we pray you to supply us any which way, so that when letters of payment will arrive, we will have the money and interest will not pile up on top of interest $[\ldots]^{15}$

Last but not least, there was also a problem of appearances to be maintained in order to be considered well at court and to be seen as worthy of being the official representatives of the Republic. Pecci writes to the Balìa saying "we will look to provide ourselves and our servants with [suitable] clothes and we will start negotiating with monseigneur of Arras and as soon as we will have our first clothes we will visit His Most Reverend

14 ASS, Balìa 722, n. 6 [30 Mar. 1550] "Noi qua per non manchare de l'honore publico, et nostro particulare, haviamo accattato 100 scudi per uno, aspettando la provisione nostra da Vostre Signorie per poterli rendare, et così le preghiamo [...] non ci manchino di mandarla subito con la licentia, acciò potiamo con una parte paghare i debiti et con l'altra ritornarcene."

15 ASS, Balìa 722, n. 32 [21 Apr. 1550] "Noi siamo stati aspettando fin'hora qualche provisione di denari da Vostre Signorie et l'aspettiamo ad ogni hora, et perché non potiamo più, caso che non ci vengha ordine loro domane o l'altro, saremo forzati andare fino in Anversa per una sera a provederci là da che qua non è modo nissuno, et se bene sarà con danno et poca reputatione publica et nostra, dovaremo essare scusati per havere indugiato quanto più si poteva a fare questo passo, essendo vissuti già più giorni con denari accattati, et però le preghiamo che voglino per ogni modo provedere, acciò che venendo le lettere de paghamenti possino essere sodisfatte, et non habbino a correre interessi sopra interessi." 
Lord." On the same day, another letter reports "tomorrow or the day after tomorrow at the latest we will have our clothes ready to go out and negotiate in your service." 16

Though in some ways private, Pecci's itinerary was also, presumably, an official document meant to be useful to future envoys. The government would use the first-hand information Pecci had gathered to plan future embassies with a more precise understanding of costs, distances, travel times, as well as probable difficulties and delays to be encountered on the way. ${ }^{17}$ Pecci indicates very precisely where he and Guglielmi ate (which allows us to appreciate better how difficult it was to find food in war-time), but he never provides information on the actual food they consumed, though he does report that in Brussels they drank beer (fol. 201v). In only one case he reports "we lodged very badly" (fol. 197v), but otherwise makes no value judgement on the inns and lodgings on route. As a Sienese accostumed to the hills and the dry country of the Sienese crete, he was fascinated by rivers, by their water capacity, and by the width and length of their bridges. He wrote, for example, that on the Panaro River near Bologna "there is a bridge with perhaps twenty arches" (fol. 195v); he noted that in Turin the Po River flows under a bridge with twelve arches (fol. 195v); and that close to Chambéry a large river flows under a very long wooden bridge (fol. 198r).

\section{The Journey}

After leaving Siena, Pecci and Guglielmi visited Duke Cosimo I at Poggio a Caiano ${ }^{18}$ before heading north, through the Po valley. They also stopped in Milan to visit don Ferrante Gonzaga, the Spanish viceroy in the city. Following his suggestion, and fearing the spread of the plague in Switzerland, they decided to avoid the logical and shorter route through

16 ASS, Balìa 719, n. 85 [26 Oct. 1549] "Noi intanto attendaremo alle provisioni de nostri vestimenti et di vestire la famiglia et incominciaremo a neghotiare con monsignore d'Aras, che come potremo havere le prime veste visitaremo Sua Signoria Reverendissima." "[...] domane o l'altro al più lungho haremo le veste nostre in hordine da potere uscire fuore et neghotiare a servitio loro."

17 ASS, Balìa 719, n. 75 [2 Oct. 1549] "l'arrivo nostro qua in Leone [Lione] dove siamo per forza soggiornati due dì per aspectare le nostre valigie" [our arrival in Lyon where we were obliged to stop for two days waiting for our luggage].

18 ASS, Balìa 719, n. 63 [10 Sept. 1549] "volendo noi in fatto ritornarcene per seguire il viaggio nostro con ogni sollecitudine, ci astrenze a restare seco a disinare, di sorte che per la sera non si potè passar Fiorenza" [willing to go back to follow our journey, he obliged us to remain for lunch, so that for the day we had not the chance to go over Florence]. 
the Gotthard Pass directly north from Milan, and head instead west to the Mont Cenis Pass in Savoy so as to reach Flanders by way of France (to backtrack to Trent and go through the Brenner Pass into Austria would have lengthened the journey considerably). ${ }^{19}$

One of the most urgent difficulties they had to face was that letters could be very slow in reaching both the Sienese government and the ambassadors, thus creating loops in the efficient progress of the mission, as Pecci noted many times.

[...] for some days, while we will cross France, we think it will not be easy to send letters, and thus we ask you to excuse us and not to accuse us of being lax if you will not receive frequent messages until we are out of this province $[\ldots]^{20}$

[...] considering that in September we wrote from Bologna on the $10^{\text {th }}$, from Piacenza on the $15^{\text {th }}$, from Milan on the $18^{\text {th }}$, from Torre al Pino close to Lyon on the $29^{\text {th }}$, and in October from Lyon on the $2^{\text {nd }}$, from Paris on the $17^{\text {th }}$, from Brussels on the $26^{\text {th }}$ to the Quattro and to the Lords, and in November on the $3^{\text {rd }}$ to the Quattro and to the Lords, on the $7^{\text {th }}$ equally to both, and on the $12^{\text {th }}$ we are greatly amazed that we did not get any receipt and we fear we have not been served well by those who brought the letters considering that from Your Lords the letters come slowly and infrequently $[\ldots]^{21}$

They then moved through Piedmont and Savoy and crossed the moun-

19 ASS, Balìa 719, n. 67 [18 Sept. 1549] "et così faremo la strada più sicura et più comoda per il sospecto et pericolo della peste del camino de svizzeri, et per la lunghezza maggiore che sarebbe per la via di Trento" [and thus we will take the surest and most comfortable way because of the suspicion and fear of the plague on the road of Switzerland and also because the road through Trent is longer].

20 ASS, Balìa 719, n. 67 [18 Sept. 1549] "per qualche giorno, mentre che saremo in questo passare della Francia pensiamo che ci accadarà [sic] difficilmente la commodità di potergli inviare nostre lettere, et però le preghiamo che ci habbino per escusati et non ci imputino di negligentia se per fin che non saremo fuori di quella provincia non riceveranno così spesso come vorremo de nostri avvisi."

21 ASS, Balìa 720, n. 40 [14 Nov. 1549] "considerando l'havergli scritto in settembre di Bologna a x, di Piacenza a xv, di Milano a xviii, et della Torre al pino vicino a Leone de xxix, et d'ottobre da Leone ali ii, da Parigi a xvii, da Brusselle a xxvi a Quatro et al magistrato, et di novembre ali iii, ali Quatro et al magistrato, ali vii parimente a l'uno et a gl'altri, et ali xii ci maravigliamo molto che non ce ne sia accusata alchuna [ricevuta] et dubitiamo non ce ne sia stato fatto mal servitio da chi l'ha portate et massime vedendo che da Vostre Signorie Illustrissime venghano così lenti et così rari gl'avisi.” 
tains through the Mont Cenis Pass. This part of the journey was characterized by the loud sound of water falling down mountains "which is almost deafening" (fol. 198v). In Lyon, after borrowing some money from a Lucchese merchant, Pecci, being an intellectual, immediately bought some legal books that, unfortunately he does not list (fol. 198v). His interest in the law was evident in Chambéry when he noted "we found here the first Rota court" (fol. 198v). After Chartres, Nemours, Fontainebleau and Melun, the two travellers reached Paris. Pecci found that the city was "large and full, neighbourhoods are very large, houses are made of wood; [it is] very crowded" and "full of jewellers" and there were endless shops of everything (fol. 199v). He clearly played the tourist and climbed the bell-tower of Notre Dame. After three and a half days Pecci and Guglielmi headed for Saint-Denis and visited the abbey to see its many relics and beautiful statues. Pecci was fascinated by the tombs of French kings, and especially by that of King Louis XII and his wife Anne of Brittany, portrayed twice in sculpture on the tomb, once alive and once dead (fol. 200r). Then he recalled the coins, precious stones, crowns that he had seen, as well as a small crucifix carved from the wood of the Holy Cross; Charlemagne's sword, and many things that Pecci did not care to note ("non presi cura di scriverle"; fol. 200r). On 2 November they reached Brussels, where the emperor was staying; but they had to wait until 25 November to finally have their first audience with him. Pecci's only comment in his journal on that audience was that "His Majesty was in a very bad condition" ("Sua Maestà quale in vero era molto male conditionata"; fol. 201v). Charles V was in fact recovering from gout and was being treated with "acqua del legno", that is, Gaiac wood (guajacum officinalis). The Sienese envoys were appreciative of the audience and sent further details about the emperor's health in the letter to their government. They noted, for example, that

the [emperor's] great kindness repaid the long wait time, and especially because we found him to be so weak and feeble because of his diet, so that we considered it a great courtesy that he listened to us, and so having been informed by monseigneur of Arras to be short both on account of his weakness and because the emperor was already informed about the situation in the city, we summarized the contents of your instructions. ${ }^{22}$

22 ASS, Balìa 720, n. 50 [26 Nov. 1549] "la gran benignità ricompensò la longa tardanza del haverla aspettata, et massime che la trovamo tanto fiacca et debile dela dieta che ci parse grandissima cortesia che la ci udisse in quel termine, et così essendo stati prima avertiti dal detto Monsignor [d'Arras] che procurassimo d'esser brevi et respetto ala debileza sua et respetto a l'esser ella già benissimo informata dele cose dela città, andamo ristregnendo la sustanza dela notola." 
In describing the city of Brussels Pecci noted that it is "as large as Siena, maybe more, and more crowded" (fol. 201v); its churches had very good organs, and they played music also with church bells. Women were beautiful and they dressed like Sienese widows with high-necked dresses and an overdress; their coat was shorter and made of silk; they wore black socks; shoes were not high heeled; women did not make themselves up and were "delicate." The men, instead, dressed like Sienese courtesans (presumably to Pecci's disappointment). They all spoke French, a language that was also taught in school.

The city of Malines, which the ambassadors reached on 16 December, was "large and beautiful and happy, with beautiful streets; a very large river flows through it and it is navigated by large boats" (fol. 202v). Here Pecci saw "the bird of Emperor Maximilian" - a white water bird with a large and long beak (presumably a pelican) that was fed only with fish by a woman paid explicitly to do this.

The four days spent in Antwerp offered Pecci the opportunity to see the large Schelda River, with its ebb and flow that reached as far as sixty miles inland. In the place called the Borsa, no less than five hundred merchants at a time met every day. The city was larger than Brussels and it was expanding, with new houses constantly being built. It produced tapestries, paintings (the most beautiful landscape paintings were made here, Pecci says), and gold objects. The cathedral was beautiful and the bell tower had 773 stairs to the top. The sugar refinery was "a beautiful, and indeed fantastic thing" (fol. 203v).

On 22 December Pecci and Guglielmi began their journey back to Siena. They did this while still following the court and adapting to the emperor's own travel plans. And so, they were back in Malines, then in Brussels, where they met an innkeeper named Ruggiero who had been in Siena at the time of Pandolfo Petrucci and together they recalled many people, such as Bartolomeo Pecci, Lelio's father Giovanni and his uncle Pietro, as well as some Tolomei (fol. 204r). In April they were again in Antwerp, then they went again to Malines and to Brussels, and eventually to Louvain, always following Charles $\mathrm{V}$ and his court. In Louvain Pecci noticed that the university was large, with 8,000 students enrolled, that all its departments were separated (presumably that they were in different buildings), and that its most important department was theology (fol. 204v). On 2 June Pecci and Guglielmi left Louvain, still following the court, for Aachen (where they visited the tomb of Charlemagne) and then Cologne, which Pecci noted was traversed by the Rhine River and had tall and beautiful brick houses, well kept large streets, and in the main church 
there were the relics of the Three Wise Men. Pecci also noted other relics, such as two gilded silver planks engraved with gold figures and precious stones. The city tower had 200 stairs and one could admire an excellent panorama from the top.

In Cologne, on 13 June, the emperor's representative, monsignor d'Arras, summoned the two envoys and gave them the emperor's final settlement for Sienese questions and his response to their appeals. ${ }^{23}$ On 15 June they left Cologne and travelled on the Rhine through Bonn, Mainz, Worms, and Speyer, where they had a final meeting with Charles V, at which time they were officially authorized to return to Siena.

Having left the imperial court, Pecci and Guglielmi journeyed through Ulm, where Pecci noted that "the city crest is the balzana [the Sienese crest], but with black on top" (fol. 209v), the women were quite beautiful and in the main church the holy images had been removed [for religious reasons], but then some had been put back on four altars. Then they visited Augsburg, home to the Fugger merchant family, where the water was taken from the river Lech and then distributed through all the city by millruns. The city produced weapons, clocks, and small ornamental pieces like studioli, as well as corduroy. There were beautiful gardens with fountains and abundant fruit trees, the main church was not that beautiful, but there were holy images in it. And here, too, the women were beautiful. After spending nineteen days in Augsburg, the pair moved slowly through the southern part of Germany (where Pecci notes "We ate some snow"; fol. 211r), Innsbruck ("A small castle with beautifully decorated houses"; fol. 211r), and then Trent, where they re-entered Italy. In Rovereto, Pecci noted with joy that the church bells toll the hours "our way" ("a modo nostro"; fol. 212r). They went through Verona ("There is a coliseum, rounded outside and oval inside, smaller than the Roman one, but better preserved"; fol. 212v) and Mantova, where there were many Jews. They eventually reached Bologna, then Florence, and then, on 10 August 1550, on the feast day of St. Lawrence, "in the name of God at sunrise we arrived at the gates of Siena" (fol. 214r).

\section{Conclusion}

Lelio Pecci was certainly a man of his time. He had presumably never left Italy and Rome was probably the farthest he had travelled before this offi-

23 No official letters sent by the ambassadors to the government with the report of the emperor's decisions for the period June-September are kept in the Archivio di Stato. 
cial appointment to visit the emperor in Flanders. He knew his assignment was of vital importance for the liberty of the Republic of Siena. He took pride in having done his best, but clearly felt disappointed at the emperor's decision to proceed with the construction of the fortress. While out of the country he kept his government thoroughly informed and, for his own self, carefully noted all the places he visited and the new things he had seen.

Pecci's travel journal offers many suggestions for a variety of different readings. At first the journal seems to be only a scrapbook, a collection of notes that the author had planned to rework into a more structured and expanded narrative once he had returned home. If this was the intended purpose for the notes, it seems strange that Pecci never elaborated on important buildings, for instance, or on the many details of the places he visited - he simply limited himself to offering a few, superficial observations. Perhaps Pecci feared that overly detailed notes of the cities and places he visited could be interpreted as spying, as a collection of sensitive information that could be used against the host cities or countries, or that such a detailed journal could fall into the wrong hands and be used in the wrong way. Such considerations might help to explain the total lack of any political information in the journal. And this might also explain the reason for the long lists of relics entered in the journal. It is abundantly clear from Pecci's language that he did not even remotely believe these relics to be authentic, so we might assume that by listing them he might have been trying to show that, as a good Catholic, he did pay attention to religion. Perhaps for this reason he noted that the town of Mainz was "ugly, poor and they are all Lutherans" (fol. 208v). It is also possible that in the first part of the journey Pecci was simply too busy with his official duties to spend time taking copious notes, so he limited himself to a few sketched comments to be reworked later. In the second part of the journey, as he travelled through Germany on his return home, Pecci had more free time and so, not surprisingly, these last folios of the journal are much more complete and detailed-oriented in their descriptions.

Like any traveller, Pecci noticed the differences and similarities between the places he visited and the places he called home. Wherever he went, he looked for signs of a Sienese presence. In Speyer he noted that the coat of arms of Piccolomini was painted on the façade of a house; in Ulm, the city coat of arms reminded him of the Sienese balzana, but reversed. In Paris, he visited his fellow countryman Costantino Ugurgieri. Pecci clearly missed his home town and the things he was accostumed to. At the same time, he was in awe of the new things he encountered-he frequently used the adjective "infinito/infiniti" [endless] to highlight the quantity and 
quality of things that were new for him. He noted everything-rivers, large fields, people, goods, cities, and relics-and in this manner remembered what was clearly a once-in-a-life-time experience for him. Informative and exciting as the journey might have been, in the last line of his journal we can, however, definately detect his relief, after almost a year of travelling in foreign lands, at being once again safely back at home.

The Medici ARChIVE PRoJeCt, FLORENCE 


\author{
APPENDIX \\ The Travel Journal of Lelio Pecci \\ From His Mission to Flanders (1549-1550)
}

[fol. 195v]

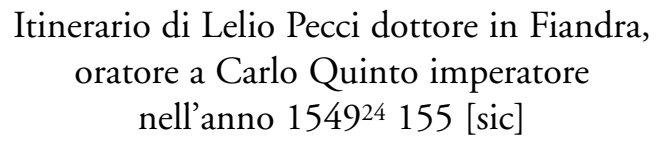

A chi leggierà

Quando nel leggere si trovarà "arrivamo", "fumo", "desinamo", "allogiamo nel tal luogo miglia tante", o simile modo di dire, vuol dire che dal luogo più vicino, dal quale si fa mentione, che partino a quello, dove arrivamo quante sono miglia tante, come quando partimo di Siena allogiamo a l'Abbadia all'Isola per miglia sei, cioè da Siena all'Abbadia a Isola sono miglia sei; quando si trovarà "a miglia tante, trovamo el tal luogo a tante el tale $\&$ a tante el tale", dove desinamo, alloggiamo e simili, vuol dire che da quel luogo più vicino, donde desinamo, o allogiamo simili, e ci partimo al tale che trovamo, vi sono miglia tante, e dal medesimo pure, d'onde [sic] partimo al tale ve ne sono tante, pigliando sempre la distantia dal luogo più vicino, ove fermamo a desinare o a alloggiare, e si semplicemente da quelle, quale più d'appresso sia notate, come quando partimo di Fiorenzuola dove a miglia 8 trovamo Scarca l'asino, a 14 Lojano, dove desinamo a miglia 8 , poi Pianoro a 16, Bologna // [196r] a 16 Bologna, cioè da Fiorenzuola a Scarcalasino [sic] ci sono miglia otto, e da Fiorenzuola pure a Lojano ce ne sono 14, e da Lojano poi a Pianoro ce ne sono 8, e da Lojano pure a Bologna ce ne sono sedici.

\title{
Il viaggio fatto nella Legatione a Sua Maestà Cesarea
} da me Lelio Pecci, e Alessandro Guglielmi per l'ordinario.

Partimo di Siena il dì 6 di Settembre 1549 in venardì circa hore 20 1/2, allogiamo all'Abbadia a Isola per miglia sei; il dì seguente desinamo a $S$. Casciano per miglia 18, alloggiamo di poi a Fiorenza per miglia otto; il dì seguente, che fu domenica, andamo a visitare el Duca di Firenze al Poggio, luogo di Sua Excelentia lontano da Fiorenza dieci miglia, ove desinamo.

24 The writer apparently forgot to add " 0 " to the date in order to form " 1550 ".

The "155" is lacking in Fumi/Lisini, Genealogia p. 125 b. 
Tornamo la sera in Fiorenze in poste, come eravamo andati. Il dì seguente desinamo a Scarparia per miglia quattordici; alloggiamo a Fiorenzuola per miglia dieci. Il dì seguente a miglia 8 trovamo Scarca l'asino [sic], a 14 Lojano, dove desinamo; a miglia otto si trova Pianoro, finita la scesa della Montagna a 16 Bologna, dove alloggiamo, e ci fermamo il dì seguente, e l'altra mattina a desinare. Partimo poi e vicino a Bologna trovamo un fiume grosso, dove è un ponte con forse 20 archi; passato il fiume Panara [sic] si trova il passo di S. Ambrogio, dove si paga. Allo // [196v] Allogiamo la sera a Modana per miglia venti. Partimo la mattina seguente, e a 6 miglia trovamo il fiume Sechia assai grosso; a 7 Rubiera castello molto forte, a 15 Reggio, dove desinamo. Alloggiamo la sera a S. Ilario ${ }^{25}$, villa per $\mathrm{M}^{\mathrm{a} 26}$ quasi a $1 / 2$ miglio. La mattina seguente trovamo il fiume Lente assai grosso, dove si paga il passo, a 6 trovamo Parma, dove è il fiume, che da il nome alla città; trovamo il fiume Taco, passamolo con la barca; a 13 Castel Guelfo, di poi a 16 Borgo a S. Donnino, dove desinamo. La sera allogiamo a Fiorenzuola castello per miglia 9, dove passa il fiume Larda: vi è un ponte con archi 12. La mattina seguente fumo a desinare a Piacenza per miglia 12, dove visitamo don Gratia Mandrien governatore; a 2 miglia il fiume Po, la sera allogiamo a Reghegnago villa piacevole, dove vedemo ballare, per miglia 13; la matti[n]a a miglia q[uattro] trovamo Lodi e a 17 Marignano, dove passa il fiume Lampo, e quivi desinamo. La sera fumo in Milano per miglia 10, dove fermamo due giorni integri seguenti e $1 / 2$ coll'imbasciatore de la Repubblica m. Girolamo Tolomei. Visitamo don Ferrante Gonzaga generale di Sua Maestà Cesarea dell'arme in Italia ala Gualtiera overo Gonzaga luogo di Sua Excelentia, e un altra [sic] volta in Milano, e desinamo con Sua Excelentia ${ }^{27}$; si visitò ancora don Giovanni De Luna castellano, che già era stato in Siena // [197r] in Siena a nome di Sua Maestà e ancora messer Francesco Grasso stato Capitano di Giustizia in Siena, e M. XICCCo ${ }^{28}$ [sic] Secco Capitano di Giustizia in Milano: m. Alesandro Visconte per essere Potestà in Cremona non si visitò.

A dì 9 Settembre in giovedì doppo desinare partimo di Milano, allogiamo la sera a Malente villa per miglia 14. La mattina seguente a 2 miglia trovamo Bufaloro ${ }^{29}$ villa, a 3 il fiume Resino in due rami passamo con barca;

\footnotetext{
25 Sant'Ilario d'Enza.

26 "met. 9 e 1/2", Fumi/Lisini, Genealogia p. 125b; perhaps "Modana."

27 “e un'altra [...] Excelentia” lacking in Fumi/Lisini, Genealogia, p. 125b.

28 "Niccolò" Fumi/Lisini, Genealogia, p. 125b.

29 Buffalora.
} 
a 7 si trova una collina netta et assai grande, quale era la caccia del Duca di Savoia. A 14 trovamo Novara città, dove desinamo; a 430 miglia di poi si trova Camariano ${ }^{31}$ castello, e a 6 Borgo pur castello, e a 10 Verze $^{32}$ città di Piemonte, e del Duca di Savoia, e quasi alle mura vi passa il fiume Siesa ${ }^{33}$ assai grosso, quale fa confino al Piemonte: quivi visitamo il Duca di Savoia e allogiamo. La mattina seguente, a 8 miglia trovamo S. Germano castello, a 12 Santo Ia[como?] $]^{34}$ e a 16 il borgo, e da $\mathrm{S}$. Ia[como?] ${ }^{35}$ al Borgo è campagna tutta piana herbosa e senza ${ }^{36}$ arbori, o macchie, e quivi desinamo. Allogiamo poi la sera a la Boscarina per miglia 3, dove visitamo il Governatore quasi amalato; la mattina seguente a 9 miglia trovamo Livorno [sic] castello, e a 8 Crescentino pure castello a fine del Piemonte, dove desinamo; di poi a un miglio passamo il fiume Po, a piedi la Verruga [sic], e a 4 miglia trova // [197v] trovamo S. Bastiano fortezza e a 4 miglia $1 / 2$ Fizano $^{37}$, a 16 Audagiano, dove allogiamo e male. La mattina seguente fumo a desinare a Chiesi [sic] per miglia dieci, dove ricevemo il salvocondotto del Prencipe di Melfi per il trombetto del signor Don Ferrante di potere passare sicuramente per la Francia; di poi a miglia sei trovamo Turino, accanto al quale passa il fiume Po sotto un ponte di dodici archi. Turino é quadro, non molto grande, in ogni cantone è un baluardo nuovo gagliardissimo: trovamovi l'ammannime ${ }^{38}$ [sic] per fare l'ale della muraglia; sonovi fossi, ma erano senza acqua. A 14 si trova Riula ${ }^{39}$ castello, e a 16 Arrigliano $^{40}$, dove allogiamo. Il dì seguente seguendo fra due montagne fino a Susa città dove desinamo; facemo miglia 16 e in una colonna del portico della strada dinanti all'hostaria nostra in una pietra vi lessi questo epitaffio:

CORNELIAE SALONINAE AUG. CONIUGI. IMP. CAES. P. LICINI GALLIAENI AUG. ORDO. SPLENDIDISS. SECUSINO.

30 "quattro" Fumi/Lisini, Genealogia, p. 125b.

31 Camerano.

32 Verzè (Novara).

33 Sesia.

34 "Santo Ia" Fumi/Lisini, Genealogia, p. 125b.

35 "S. Jacopo" Fumi/Lisini, Genealogia, p. 125b.

36 "esenza” Fumi/Lisini, Genealogia, p. 125b.

37 "Fizzano" Fumi/Lisini, Genealogia, p. 125b.

38 "mettere all'ordine, allestire, preparare" [to tidy up, to prepare].

39 Rivoli.

40 Avigliana. 
A allogio fumo poi a la Novalese ${ }^{41}$ [sic] per miglia 12, qual villa è a piedi del Monsenese ${ }^{42}$, e a canto vi è una montagna di salita a dritto dicano di miglia 15. La mattina seguente saglimo con muletti il Monsenese per miglia 3 donde $^{43}$ escano acque assai; ne la cima caminamo a piano per miglia 4 dove trovamo un laghetto, di poi scendemo per due miglia fino a Lanemburgh // [198r] dove desinamo, e da ogni banda del Monte vi sono li arramacciatori ${ }^{44}$. Facemo in tutto miglia 9, di poi caminamo sempre per valle fra montagne longo un fiumetto fatto dall'acque, e i ... [sic $]^{45}$ fano zazare $^{46}$ a le montagne e grandi; allogiamo a l'Ausera ${ }^{47}$ castello per miglia 9. La mattina seguente desinamo a $S$. Michele ${ }^{48}$ castello per leghe 5 , che una di queste leghe fa tre buone miglia. Allogiamo la sera a S. Gian de Moriano ${ }^{49}$ per leghe due, castello grosso dove trovammo un porco impiccato per la gola per haver guasto una putta, e il luogo dove era stata bruciata una cavalla et un huomo di paglia per havere usato seco, e che il vivo si fuggì. La mattina seguente a desinare a $\operatorname{Ughbel}^{50}$ per leghe 6 , di poi tre leghe trovasi la Ciambra $^{51}$ villa grande, e a 4 Momiliano $^{52}$, dove accanto passa un fiume grosso sotto ponte di legname longhissimo, e quivi allogiamo. La mattina a desinare a Ciamberi ${ }^{33}$ per due leghe, per dove sono vigne assai, se bene è valle fra montagne altissime, e vi trovamo la prima Rota di giustizia; di poi passamo la Giubelletta montagna per una legha [sic] con cavallette [sic], et alloggiamo al Ponte del Vigin per leghe tre in tutto. La mattina seguente caminando per tre leghe desinamo a la Torre Dupin ${ }^{54}$, e uscimo de le montagne

41 Novalesa (Turin).

42 Moncenisio.

43 "d'onde" Fumi/Lisini, Genealogia, p. 126a.

44 The etymologic dictionary has 'noise of leaves and branches', but it is also used for the noise of people fighting or coming to blows, www.etimo.it

45 "vi" Fumi/Lisini, Genealogia, p. 126a.

46 Perhaps similar to the Italian hairstyle 'zazzera' (the bob hairstyle), a man's hairstyle long enough to touch the shoulders.

47 Oulx?

48 Saint Michel-de-Maurienne, Savoy.

49 Saint Jean-de-Maurienne, Savoy.

50 Aiguebelle, Savoy.

51 La Chambre, Savoy.

52 Montmélian, Savoy.

53 Chambery.

54 La Tour du Pin, Isère. 
fra le quali per valle havevamo caminato 5 giorni continui, sempre longo un fiume fatto dall'acque che cadono dalle mon // [ 198v] dalle montagne, il quale correndo fra sassi, e qualche calata fa romore assai, che quasi assorda; la sera fumo alloggio [sic] a la Volpigliera per leghe quattro. La mattina di poi, che fu l'ultimo de Settembre fumo a desinare a Leone ${ }^{55}$ per leghe cinque in lunedì. Leone è posto in piano e in costa ma il bello [sic] è mercantile et al piano passa per essa il fiume Rodano e la Sorra ${ }^{56}$ [sic], la quale va tanto piano che non si conosce per donde corra, tutti due sono navigabili, hanno nella città archi bellissimi sopra de quali vi sono botteghe infinite. Il luogo dove convengano i mercanti, lo chiamano il Cambio: ci fermamo 4 giorni, dove ci fece pasto m. Matteo Balbani mercante lucchese, e ci servì di 150 scudi d'oro di sole [sic] da rimetterli IC ${ }^{57}$ Anversa a m. Tomaso suo fratello senza interesse alcuno, de quali io ne presi cento, de quali ne comprai libri di legge; dove trovamo ancora m. Augustino Puccini lucchese pure. Alli 4 d'Ottobre in venardì doppo desinare partimo di Leone, alloggiamo a la Brella per tre leghe. La mattina seguente a tre leghe trovamo Parrara villa e a 6 Sansaforino [sic] castello, dove desinamo, allogiamo la sera a Roana ${ }^{58}$ villa grossa, accanto alla quale passa il fiume Suera ${ }^{59}$ [sic] assai grosso, dove il Gallina s'imbarcò cole valigie, facemo leghe tre. La mattina seguente desinamo a la Pacodiera ${ }^{60}$ per leghe 4, la sera allogiamo a la Pelis ${ }^{61}$ castello per leghe 4; la mattina di poi a desinare // [199r] desinare a Varens ${ }^{62}$ per leghe quattro, la sera allogio a Molino63 città e capo dello Stato già di Borbone per leghe sei, e accanto alla porta passa il fiume Luera ${ }^{64}$. Il dì seguente a desinare a s. Piero a Motiers ${ }^{65}$ per leghe sette, di poi a due leghe si trova Magni ${ }^{66}$ e di poi a 5 caminando per la Rua dell'Inferno, che fa gran-

55 Lione.

56 Saône anticamente Arar [formerly Arar].

57 In the ms these letters are between the two words, possibly meaning "in cambio" or "in conto"; "In Anversa" Fumi/Lisini, Genealogia, p. 126a.

58 Roanne, Loire.

59 Loire?

60 La Pacaudière, Loire.

61 Lapalisse, Allier.

62 Varennes-sur-Allier, Allier.

63 Moulins, Allier.

64 Loire.

65 Saint-Pierre-le-Moûtier, Nièvre.

66 Magny-Cours, Nièvre. 
dissimo fango l'inverno, Niversa ${ }^{67}$, dove alloggiamo, e vi passa il fiume Luera ${ }^{68}$. Il dì seguente a desinare a la Charité69 per leghe sei e di poi s'alloggiò a Pogli 70 [sic] per leghe tre. La mattina seguente a quattro leghe trovamo Conno $^{71}$ [sic] castello, e a 7 Novi $^{72}$ [sic] villa dove desinamo; di poi ad una legha si trova Boni ${ }^{73}$ castello e a quattro Briara, ${ }^{74}$ dove alloggiamo la sera, e desinamo ancho la mattina, aspettando il Gallina colle valigie; la sera poi alloggiamo a Nove ${ }^{75}$ [sic] castello per leghe cinque.

La mattina di poi a desinare a Montargie ${ }^{76}$ per leghe quattro, che è terra grossa, e bella, et è del Duca di Ferrara per il ducato di Sciatres 77 [sic], havuto già in dote dal Re Luigi ${ }^{78}$ per una sua figlia ${ }^{79}$. La sera l'alloggio a Nemurs ${ }^{80}$ per leghe sette; la mattina a desinare a Fontana Bliò ${ }^{81}$ luogo del Re di Francia molto bello, e ricco per l'edifitio. La sera l'alloggio a Melun ${ }^{82}$ per leghe quattro, per dove passa il fiume Senna, e vi fa isola. La mattina di poi a desinare a Villa nuova di San Giorgio ${ }^{83}$ per leghe sei, dove pure passa il fiume Senna, la sera alloggiò in Parigi per leghe 4 // [199v] per leghe quattro. Passavi dentro il fiume Senna, e vi fa isola et è domandata la città ${ }^{84}$ et è la minore parte: la parte verso levante è chiamato Università et è un poco maggiore; la parte verso Occidente, quale è la maggiore, la villa. Il fiume è grosso assai e navigabile: solo vi è un ponte murato, gl'altri sono

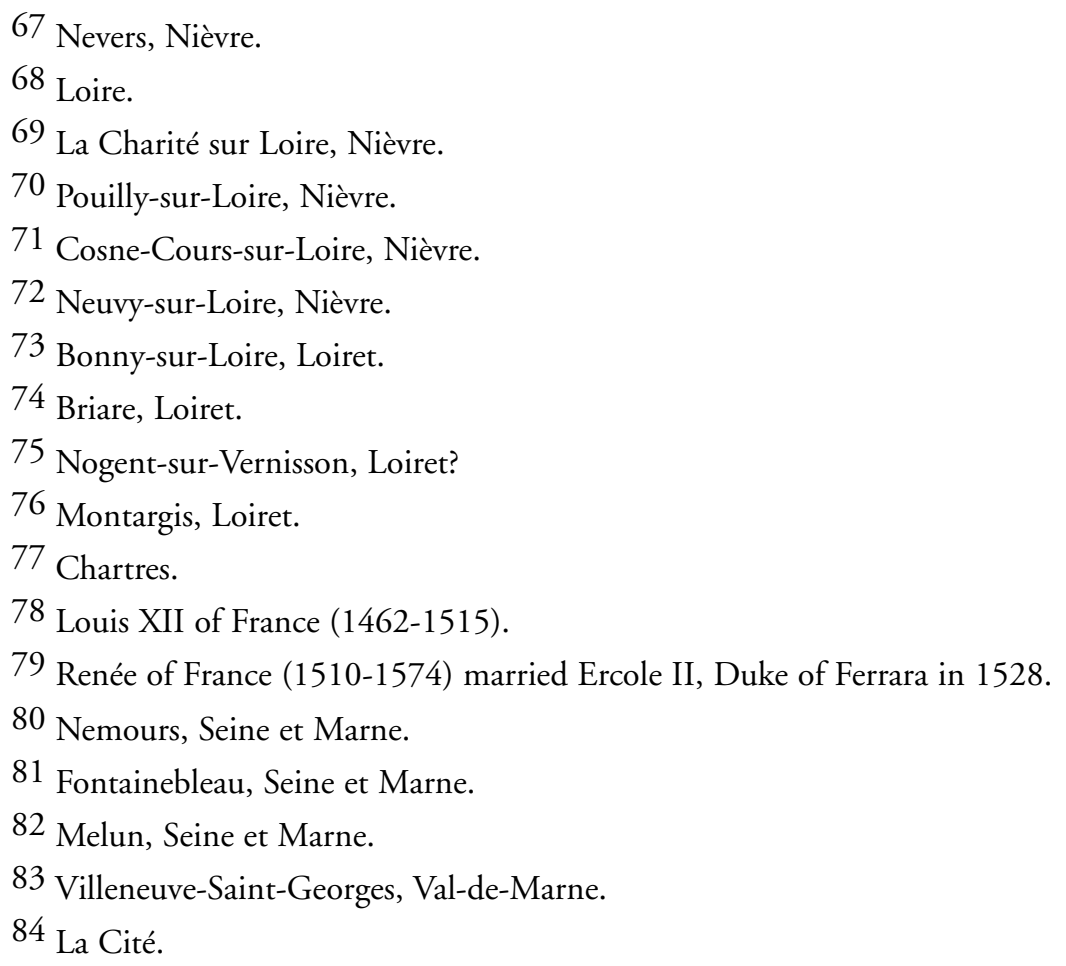


di legname. Sopra essi vi sono bottighe assai, la città è grande e piena, e li borghi sono grandissimi: case assai di legname, gente infinita, orefici infiniti. Nel Palazzo legale 85 [sic] vi è la Cappella, vi riseggano li offici, e in tre o 4 sale grandi vi sono infinite botteghe d'ogni cosa; né è da andarvi con li speroni in piè, perché vi sono assai che fanno crulla [sic] per cavarli e torli, overo pagare soldi. Fumo nel campanile di nostra Dama, ${ }^{86} \mathrm{ci}$ trovamo m. Constantino Ugurgieri. Pigliamo da mercanti lucchesi scudi 100 d'oro di sole per rimetterli in Anversa, cioè 50 per uno: volse uno scudo per interesse. In Francia cominciando a Leone, e seguendo a Parigi fino a li confini lo scudo [in marg: parpagliuola soldo del Re. Leardo] fransese ${ }^{87}$ [sic] di sole vale parpagliuole, overo soldi del $\mathrm{Re}, 45$ et il "p" overo parpagliuola vale 4 leardi $4^{\circ}$ che a ragione di nostra moneta valutando lo scudo fransese $1.8 \mathrm{~s}$. 3 vale la parpagliola, overo soldo del Re, soldi $883 \mathrm{~d}$. 7, ma lo scudo // [200r] lo scudo detto Italiano, se bene fanno differentia da conio e conio, che il genovese vi vale qualche cosa più, comunemente vale parpagliole 42, dove a nostra moneta valutando lo scudo $8981^{190}$. in questi tali scudi italiani, la parpagliola vale B ${ }^{91} 3$ den. 9 et il franco, overo l. in Francia vale 20 parpagliole, overo B ${ }^{92}$ [sic] del Re.

Stemo in Parigi giorni tre e mezzo, e così alli diciotto in venardì doppo desinare partimo di Parigi. Alloggiamo a san Dionigi ${ }^{93}$, castello grosso per due leghe, dove nell'Abbatia di S. Dionigi vedemo il tesoro, quale fu portato di Constantinopoli, quale si partì con li Veneziani, che la parte loro hoggi si chiama il Tesoro di San Marco. Ne la città vi è un Crocifisso di grandezza di un putto di quattordici anni, tutto massiccio di oro, e nell'istessa chiesa vi sono le sepolture di tutti i Re di Francia morti, eccetto di Carlo Magno, che è in Gapersgnano ${ }^{94}$ [sic], che sono tutti sculti di pietra di rilievo a giacere, come sopra una cassa grande. Quella del re Luigi è la

85 “regale” Fumi/Lisini, Genealogia, p. 126b.

86 Notre Dame.

87 "franseo"Fumi/Lisini, Genealogia, p. 126b.

88 Corrected on "p" for parpagliola.

89 "ducato" Fumi/Lisini, Genealogia, p. 126b.

90 "L." Fumi/Lisini, Genealogia, p. 126b.

91 perhaps "lire".

92 "sol.” Fumi/Lisini, Genealogia, p. 126b.

92 "sol." Fumi/Lisini, Genealogia, p. 126b.

93 Saint-Denis, Seine-Saint-Denis.

94 Aquisgrana, Aix-la-Chapelle. 
più bella, che è di marmo, et vi è sculto vivo, con la Regina sua moglie, e di poi anche morti tutti due. Nella stanza poi del Tesoro vedemo uno tazzone, dicano del re Salomone // [200v] con testura d'oro e commesso di pietre preziose; uno calice d'agata di grandezza ordinaria. Un ritratto di Marco Antonio e uno d'Ottavio sculpito in cameo di grandezza di più di quattro dita per ogni verso; altre diverse medaglie e pietre preziose, ma più piccole assai; le corone, con le quali si coronano i re e la Regina, con infinite gioie, et altre gioie separate. Reliquie infinite e fra le altre un Crocefissino del legno della Santa Croce; il scettro, il manto, lo stocco e li speroni del Re; la spada del re Carlo Magno; quella del vescovo Turpino95 [sic]; il corno dicano d'Orlando di dente di elefante, ma non è intero. Uno ognone ${ }^{96}$ [sic] dicano di grifone grande quanto ogni gran corno di corriero di colore bigio; la spada della Pulzella ${ }^{97}$ et altre infinite cose, che non presi cura il scriverle. Partimo la mattina e fumo a desinare a la Ciappella ${ }^{98}$ per leghe quattro, la sera a alloggio a $\mathrm{S}$. Lis ${ }^{99}$ per leghe due, quale è castello grosso; la mattina di poi a desinare a $\mathrm{La} \mathrm{Croix}^{100}$ per leghe sei, la sera a alloggio a Compiegni ${ }^{101}$ terra buona per leghe quattro. Il dì seguente a una lega trovamo il fiume Dan [sic] e Siesi ${ }^{102}$ [sic] villa accanto, a li tre trovamo il fiume Rosa ${ }^{103}$, quali tutti due passamo in barca a 5 Nojon ${ }^{104}$ città bella, dove desinamo e veddi una // [201r] veddi una sposa. La sera ad alloggio a $\mathrm{Nam}^{105}$, dove è fortezza con acqua intorno del fiume Soma ${ }^{106}$, che è grosso; il dì di poi a desinare a Epighi ${ }^{107}$ [sic] villa per leghe sette, di poi ad allog-

95 Turpino was appointed bishop of Reims about 754. He was one of the twelve peers of France and counsellor of Charlemagne. He became martyr between 789 and 794.

96 Claw.

97 Jeanne d'Arc, la Pucelle d'Orleans

98 La Chapelle?

99 Senlis, Oise.

100 Lacroix-Saint-Ouen, Oise.

101 Compiègne, Oise.

102 Choisy-au-Bac, Oise.

103 Oise River (formerly Isara)?

104 Noyon, Oise.

105 Ham, Somme.

106 Somme?

107 Selvigny, North? 
gio la sera a Cambraii ${ }^{108}$ città bella e libera, cioè dal Vescovo suo ma devota dell'Imperatore, dove è fortezza fatta e guardata da Sua Maestà Cesarea, e sue genti: il viaggio fu di leghe cinque.

Il giorno seguente, che fu mal tempo, a desinare a Valentiana ${ }^{109}$ per leghe sette: è città bella e la prima a la frontiera di Brabantia, dove anche allogiamo. Il giorno seguente a desinare a Monte $\mathrm{No}^{110}$ [sic] per leghe sette, dove sono fossi con acqua grandi. La sera a alloggio a Sogne ${ }^{111}$, castello grosso per leghe tre. La mattina seguente, che fu venardì alli 25 di Ottobre a cinque leghe trovamo Nostra Dama d'Aus [in marg: Auch] castello grosso, dove sono donne canonichesse che offitiano la chiesa, eccetto che di messe; a 8 leghe trovamo Bruselles ${ }^{112}$ nella quale era Sua Maestà Cesarea, entramo in essa circa hore ventidue.

La sera istessa tornò il Principe ${ }^{113}$ da la visita di Fiandra; Sua Maestà haveva finito di pigliare l'acqua // [201v] pigliare l'acqua del legno, fumo alloggiati in casa di madama Susanna vicino alla chiesa della Cappella.

Il dì 2 di Novembre in sabbato visitamo monsignore di Aras, che monsignore di Granvel ${ }^{114}$ non era ala corte. Il dì 7 di detto si rivisitò e ci mostrò le lettere e memoriale di Giovan Maria Benedetti115. Il dì 22 si rivisitò pregandolo per l'audienza di Sua Maestà; il 25 di detto a hore dieci secondo quel paese, havemo udienza da Sua Maestà, quale in vero era molto male conditionata.

Bruselles è terra grande quanto Siena o più, e forse più piena. È stata centa $^{116}$ [sic] di mura tre volte e vi sono anche le mura; per la terra passa un fiume, per il quale vengano barche assai grosse; ha fossi d'intorno con acqua. La chiesa cattedrale la domandano Santa Hulla117, dove sono bonissimi

108 Cambrai, North.

109 Valenciennes, North.

110 Mons, in the province of Hainaut?

111 Soignies, in the province of Hainaut.

112 Bruxelles.

113 Philip II of Spain (1527-1598).

114 Nicolas Perrenot de Granvelle (1486-1550) was chancellor and minister of Justice of Charles V of Habsburg.

115 Giovan Maria Benedetti was later involved in the conspiracy leaded by Francesco Bandini bishop of Siena, aiming at obtaining the help of the French king to free Siena from Spanish.

116 "cinta" Fumi/Lisini, Genealogia, p. 127a.

117 Kathedraal van Sint-Michiel en Sint-Goedele. 
organi; la chiesa è assai grande e bella, a navate, usano le croci ${ }^{118}$ con crocifissi ne cimiteri. Fanno musica con le campane di 12 o 14 e le suonano come li organi: avanti suoni l'hora suona una poca di musica e così alla mezza sera; ci si lavora di razze ${ }^{19}$ [sic] meglio che in altro luogo, e il segno è IB.

Lavorano stagni benissimo e d'Inghilterra, quale deve havere la rosa [sic]; ci si beve la birra, come nelle altre terre di Brabantia e Fiandra. La terra parte è posta nel piano, parte al monte; lo scudo di sole franzese, overo quello del pae // [202r] quello del paese vi vale patarre, overo plache 38 , la placha 4 leardi, il leardo due cigotti, lo scudo italiano vale plaches 37 talché a la nostra moneta a lire 8 lo scudo la placha vale sol. 4 den. 4, il ducato detto vale 40 plache; il reale di Spagna vi vale 3 plaches $1 / 2$. Per un fiorino intendano mezo ducato, cioè 20 plaches; il fiorino detto d'Alemagna valevi 30 plaches e d'una sorte - dove è sanctus Andreas sopra così segnato X - cioè sopra sanctus Andreas vale plaches 31. I filippi vagliono plaches $27^{120}$, i ridey plaches 23 , i kroli plaches 21 , mezzi fiorini con certa arme con corna nel mezzo et in un canto due schelles ${ }^{121} \mathrm{pl}$. 12, senza questa arme plaches $11^{122}$, i filippi doppi pl. 54 .

L'angelotti, moneta do [sic] inglese, pl. 62 e così vagliano per tutta Brabantia e Fiandra et Anversa parlano a lire per grossi e denari quelli mercanti che il grosso, overo denaro, lo fanno 1 placca, il p[arpagliola] ${ }^{123}$ plaches 6 , la lira di grossi 20 perché sono 120 plaches.

Le donne sono belle, portano l'habito sopra come a Siena le vedove, ma quel mantello è più corto, et è di steda ${ }^{124}$ [sic] fina, o saia negra; vanno tutte accollate, con calze tutte negre, e scarpa di trippa ${ }^{125}$ [sic] senza niente di pianella; non si lisciano, sono delicate; da uno anno in su // [202v] in su le vedove vanno come le maritate, le ciambriere ${ }^{126}$ portano sopra in testa un mantelletto increspato longo fino a mezza coscia; huomini e donne, tutti parlano fransese, e vi se ne tiene scuola; l'habito delli huomini è come

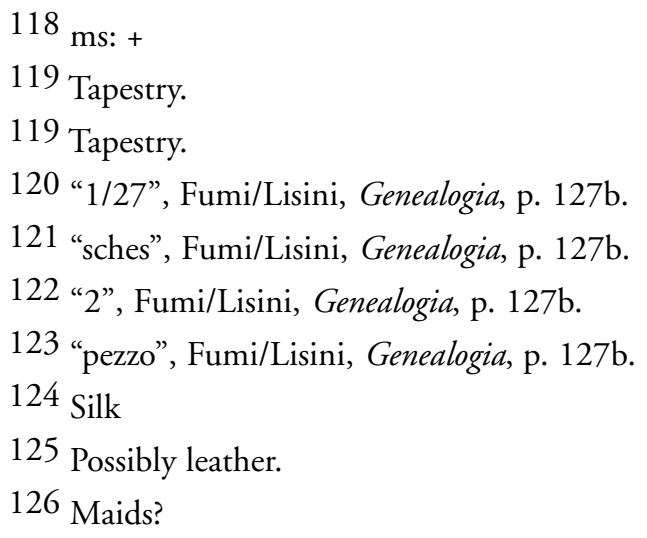


le cortigiane di Siena.

Il dì 16 Decembre doppo desinare partimo di Bruselles in carro allogiamo la sera in Malines ${ }^{127}$ per leghe quattro. La terra è grande e bella e allegra con belle strade, per dentro vi passa un fiume assai grosso e se navigha con barche grosse; vi si fanno buoni coltelli, vi vedemo l'artiglieria che vi ha fatto condurre Sua Maestà da la Magna, che sono in uno luogho 200 pezi molto belli, fra i quali vi è il gran Diavolo, che nella coda ha sette corna, quali battendoli fanno musica: sonovene [sic] due pezzi, dove sopra vi è scolpito il papa in forma di diavolo; in altri luoghi ne sono 400 pezzi più. Vedemo il danno che fece, appiccandosi già il fuoco per una saetta nella monitione della polvere, che era in un torrazzo delle mura ne la cantina, dove rovinò forse 300 case e vi ammazzò circa 150 persone; e vi vedemo l'ucello già di Massimiliano imperatore, quale è ucello aquatico [sic] e bianco col becco lungo e largo ${ }^{128}$ assai a guisa di quello che haveva anni di Prospero // [203r] di Prospero in Siena a la sua bottega. Lo tiene una donna, e quella ha sei plaches il giorno per governarlo e guardarlo, che non mangia se non resce ${ }^{129}$ [sic]. Ci dicano che ha cent'anni. Il giorno seguente doppo desinare pure in carro andamo a alloggiare in Anversa ${ }^{130}$ per leghe quattro, dove ci fermamo quattro giorni; a meza lega presso a Anversa si trova il luogo della Giustizia, dove erano più di 30 Rote piene e forse cento altri giustitiati. In Anversa vedemo le fortificationi nuove della muraglia della terra, tutta terra piena con 9 baluardi fortissimi, e poco manca a essere tutta fornita la muraglia, quale dicano essere stata di spesa fino adesso 900000 scudi; dall'altra banda della terra è il fiume Schelda ${ }^{131}$ grossissimo di larghezza di più d'una archibusata col flusso e reflusso, se bene è lontano dal mare circa 60 miglia. Vi vengano tutti li navili, per la terra passano più canali per dove vanno barche grosse, e ve ne sono di quelli che sopra sono coperti con volte, e la strada passa di sopra, se bene non li carri; la terra è grande più di Bruselles, e di continuo vi si edifica case assai. Il luogo dove mattina e sera, ogni giorno con // [203v] convengano i mercanti, che sono sempre almeno 500, lo chiamano la Borsa: redotto, con le logge in quadro, come un chiostro di frati con le volte e cortile, in mezzo con due strade che vi si conducano al rincontro sopra a li detti portici. D'ogni intorno vi sono

\footnotetext{
127 Mechelen.

128 A pelican.

129 Fish.

130 Antwerpen.

131 Schelde.
} 
bottighe d'ogni cosa posticcie, sonovi luoghi come strade coperte, quali chiamano ponti, come dove si vendono raze ${ }^{132}$, dove dipinture e merciarie e orefici, che tre ne viddi; la chiesa loro cattedrale è più bella di quella di Bruselles e maggiore, ha le navate doppie, il campanile è molto bello, si monta a andare in cima, e non affatto 773 scalini. Sonovi le campane, che fanno musica; fannovisi tele di paesaggi le più belle che si faccino. Vi si vendano refi curati finissimi di scudi 10 la libra, cioè 16 oncie; nel palazzo della villa appiccato al palco vi sono ossa di cano [sic] del Gigante, che già fu signore d'Anversa ${ }^{133}$, quali sono negre, fra queste vi è l'osso della coscia, quale giudicai di longhezza di due braccia giuste, grosso a corrispondentia. Evvi la paletta della spalla grossa a quella istessa corrispondentia e due altri pezzi d'osso pure di quella egualità; evvi uno sperone dicano suo, fucci mostrato ancora la porta della sua casa; vedemo il luogo dove si raffina il zuccaro, quale è di mercanti // [204r] mercanti lucchesi cosa bella, in somma, e maravigliosa. La mercatura di quella terra d'ogni cosa è da stimarsi, che di gran lungo si lascia indietro Venetia, fumo a Vubuch luogo di Gaspare Ducci da Pescia già mercante, assai bello ma piccolo per una lega, ci fu fatto pasto la mattina da m. Vincentio Deodati e m. Girolamo suo fratello mercanti lucchesi, e la sera da Iacomo Cinuzzi; visitamo m. Tomaso Balbani, quale era amalato, e m. Turco Balbani mercanti lucchesi, ai quali di già havevamo rimessi scudi 250 presi già in Leone, e in Parigi ci visitò $\mathrm{m}$. Vincentio Orsucci pure lucchese. Alli 22 di Dicembre doppo desinare partimo d'Anversa pure in carro, e fumo la sera alloggio in Malines; la mattina seguente tornando a Bruselles per altra via, a due leghe trovamo l'oste chiamato Ruggiero, quale era stato gran tempo in Siena con Pandolfo Petrucci: si ricordava di molti, fra li altri di $\mathrm{m}$. Bartalommeo Pecci e di Giovanni buona memoria mio padre e m. Pietro mio zio, e anche cognosce Conte Tolomei; la sera alloggio in Anversa all'ostaria del Leone Rosso presso ala chiesa grande, pigliamo da m. // [204v] da m. Tomaso e m. Turco Balbani scudi 800 d'oro d'Italia per rimetterli in Siena, quali ce ne accomodorno con gran cortesia, senza volere cambio o interesse alcuno, o pura una placha per scudo come si costuma. Facemo lettere al 8 di veduta ${ }^{134}$ io per scudi 400 al Ballati e Benvoglienti e Alesandro ${ }^{135}$ pare per 400 scudi a Cacciaguerri. A questa prestantia, secondo ci fu detto, concorse unitamente tutta la natione lucchese, che fu atto molto cortese e generoso. $\mathrm{Li}$

132 Tapestry.

133 Reference to the killing of giant Druon Antigoon by soldier Silvius Brabo.

134 "veduta primo" Fumi/Lisini, Genealogia, p. 128a.

135 Guglielmi. 
detti $\mathrm{m}$. Tomaso e $\mathrm{m}$. Trovo [sic] ci fecero pasto dove furono molti altri lucchesi. Partimo d'Anversa ali 28 d'Aprile doppo desinare alloggiamo la sera a Malines con Ruggiero, la mattina fumo a disinare in Bruselles, il dì ultimo di Maggio in sabbato doppo desinare partimo di Bruselles, seguendo Sua Maestà che s'era partita la mattina alloggiamo a Lovavia ${ }^{136}$ [sic] per leghe quattro; dove eravamo stati rimessi per la speditione nostra, quale non seguì, dove ci fermamo il giorno seguente e fumo rimessi a Matries ${ }^{137}$ [sic] per la speditione. Lovania è grande e piena, ma non molto bella; lo studio vi è grande, dicano di viii ${ }^{\mathrm{m}}$ scolari et in ogni professione, ma la principale è di teologia, le scuole sono separate di ogni professione. Vi è il palazzo di papa // [205r] Adriano, dove alloggiò Sua Maestà, ma non ha apparenza; per la terra passa un canale per dove vanno barche grosse, non è forte. Il dì 2 di Giugno in [canc: giovedì] lunedì seguendo pure la corte, doppo desinare partimo di Lovania, e caminando per paese bello assai desinamo a Thilmonth castello per quattro leghe; la sera alloggiamo a Scentro ${ }^{138}$ castello per tre leghe, sempre per paese bellissimo. La mattina seguente fumo a desinare a Tongher ${ }^{139}$ castello per tre leghe, dove è Sua Maestà. A alloggio fumo a Mastriers per tre leghe, seguendo bel paese, dove la mattina seguente fumo a desinare. Sua Maestà e l'Altezza del Prencipe fece l'entrata, che è castello o terra grossa, dove l'accompagnavano quelli della terra forse con cento torce a uso nostro, come staggiuoli, ai quali erano appiccate armi diverse; per il mezzo della terra passa il fiume Mosa assai grosso, et una parte di detta terra è del Vescovo di Liegi, l'altra di Sua Maestà. Ci fermamo in Mastrie tre giorni, tra i quali fu il Corpus Domini, e l'ultimo fumo rimessi per la speditione a Colonia ${ }^{140}$, e così il sabato partimo, e fumo a desinare a Aquisgrania ${ }^{141}$ per leghe quattro, quale è terra imperiale, e vi s'incoronano l'imperatori dela prima // [205v] de la prima corona ne la sedia di Carlo Magno, quale è nela chiesa maggiore, dove anco è la sepoltura sua sopra l'altare maggiore in una cassa di bronzo e in un altro luogo di detta chiesa, assai al buio, vi è una statua di detto Carlo Magno, che sotto vi è un pilo di marmo grande per statura d'huomo, che è di marmo, e sculto e molto bello. Sono in detta chiesa, dicano, molte reliquie fra le quali un quadro di marmo di $1 / 2$ braccio, dove dicano fu cir-

\footnotetext{
136 Leuven, Vlaams-Brabant.

137 Maastricht.

138 Schaarbeek?

139 Tongeren, Limburg.

140 Köln.

141 Aachen.
} 
conciso nostro Signore; una camicia dicano di Nostra Donna; il panno sopra del quale fu decapitato san Giovanni Battista. Detta chiesa ha quattro ${ }^{142}$ porte di bronzo grande, ma pure nel mezzo per una pupula [sic] mostra antiquità. La casa publica demonstra essere antichissima, la terra ha intorno colline che la sopraffanno, non è molto grande né bella: ne la terra vi sono quattro bagni molto belli fuore forse $1 / 2$ miglio. Ve ne sono più di 40 dove è un borgo assai grande: fermamo in Aquisgranto [sic] tutto il giorno e la mattina seguente a desinare, il giorno partimo et alloggiamo a Julies $^{143}$ per quattro leghe: la terra non è molto bella né grande; si va rifacendo per essersi bruciata trascuratamente per una stalla. La mattina seguente desinamo a Bergh ${ }^{144}$ villaggio per tre leghe, delle quali una è boscho e camino mal sicuro: la sera a alloggio a Colonia ${ }^{145}$ // [206r] Colonia Agrippina per tre leghe assai boscate, benché si trovano villaggi assai, nondimeno il camino non è molto sicuro. Sua Maestà vi arrivò il giorno seguente. La città è posta in piano et ha le mura verso Germania che vi fa confino; passa il Reno fiume grandissimo di larghezza di mezzo miglio, e si naviga con barche grossissime. Dove non passa il Reno vi sono fossi doppi tutti pieni di arbori, che cuoprano le mura e ha ${ }^{146}$ un fosso e l'altro fosso vi è spatio di 20 passi tutto herboso, molto bello per farvi esercizio. La banda delli fossi, che non è verso le mura, è murata che non vi sono arbori; ha arcivescovado et è uno delli Elettori dell'Imperio. L'arme sono tre corone l'una accanto all'altra. È grande quanto Fiorenze e di vantaggio ha li edifitii alti, murati et belli, fuori dell'usanza di quei paesi; le strade sono larghe e bene poste, e tutta insieme dimostra antiquità e maestà romana. Per la città vi è qualche anticaglia d'archi, la casa publica è antiquissima [sic]; evvi un torrone di 200 scalini per dove si scuopre tutta la città. La chiesa grande non è fornita nela larghezza, la longhezza è 265 passi; sopra il campanile vi sono legni che pendano così. Vi sono in questa chiesa le teste et il resto delle ossa de corpi delli tre Magi: dicano hanno fragmenti delle corone in testa, nel mezo è posto per quanto vi è scritto // [206v] Melchior, a mano destra Baldassarre, a sinistra Gasparo. Per orna-

\footnotetext{
142 ms: $4^{\text {tro }}$

143 Julich.

144 Die Burge?

144 Die Burge?

145 Köln.

146 "fra" Fumi/Lisini, Genealogia, p. 129a.
} 
mento ${ }^{147}$ di cose donate vi sono due tavole d'argento indorato di longhezza di 2 braccia e $1 / 2$ di larghezza, una era assai pura, l'altra è di gran valuta per le figurine di rilievo d'oro appiccatevi e infinite gioie d'ogni sorte, e nel mezo vi è uno cameo quasi tondo, di larghezza di un palmo, che vi sono intagliate due teste. Sonovi ancora tre coppe d'oro grandi, una stella d'oro di larghezza d'una [canc: spalla] spalma [sic] et infiniti altri voti. Hannovi devotione incredibile. Di sotto la chiesa maggiore vi è un altra [sic] chiesa, dove sono infinite reliquie di ossa, e quasi a cataste, dicano esservi uno slevo $^{148}$ [sic] di quelli coi quali fu confitto Christo in croce, ma è in una guaina d'argento, che non si vede se non il capo assai consumato, e così una centura dicano della Vergine Maria come una fietta [sic] tessuta azzurra. Al convento de frati minori, che loro dicono di s. Orsola, vi è — dicano - la testa di santa Orsola e un suo braccio con una infinità d'altre teste, delle quali ve ne sono molte coperte d'argento, et infinite di gesso, ma senza fine sono le scoperte con una benda negra dove era la boccha. Infinite sono le cataste delle altre ossa: // [207r] dicano tutte essere de 36 mila vergini della compagnia de $\mathrm{S}$. Orsola, che noi diciamo xi mila martirizzate in Colonia. Evvi ancora un vaso di marmo assai alto, dicano essere una delle idrie [sic] ne le quali fu fatto il miracolo dell'acqua in vino. Hannovi una cosa a guisa di corno di bu [sic] overo da cornice ma bigio: dicano essare ognone d'ucello, quasi come quello a san Dionigi, benché quello è più allunato, e mostra più durezza e grossezza.

Vi è una chiesa offiziata da donne chiamate canonichesse come a Mons de Naus [sic]: ognuna vive a casa sua. Nella chiesa convengano a dire offitio fuori che la messa, e possano pigliare marito a posta loro, ma lassano l'offitio. In questa chiesa vi sono 4 spine dicano della corona di nostro Signore, e del legno della sua Croce e infinite altre reliquie. Lo studio vi è assai grande, sonovi esercitii diversi e assai, ma non mercatura grossa; la gente poco amica di forestieri, le placs è moneta di Fiandra e Brabantia ne ${ }^{149}$ si spendono. Lo scudo italiano vale 22 bazi $1 / 2$, che a otto lire la nostra moneta il bazo vale sol. 7 denari $1 \frac{1}{12}$; lo scudo fransese di sole vale 23 bazi, il bazo vale 15 pfennig che si spendono per tutta Alemagna, ma in qualche luogo il bazo non vale se non 14 pfenig [sic] // [207v] 14 pfenig. In Colonia havemo la resolutione della speditione nostra da monsignore d'Aras e segretario Vargas il dì 13 di Giugno in venardì circa hore sei doppo mezzo dì; e quando andamo a casa di Monsignore per tale effetto, passan-

147 “ornamenti” Fumi/Lisini, Genealogia, p. 129a.

148 Possibly a nail.

149 “vi” Fumi/Lisini, Genealogia, p. 129a 
do per il mercato a punto si faceva giustizia di due per havere ammazato un patrone della casa in Colonia. In casa, dove trovamo Monsignore d'Aras vi viddi intagliata la nostra arme delle stelle sole, ma non era colorita.

Adì 15 di Giugno partimmo in domenica, desinamo a Bonna ${ }^{150}$ per leghe 4, dove s'era imbarcata Sua Maestà. Il viaggio nostro fu longo il Reno, sempre che di qua e di là sono poggetti dove sono infinite vigne e castelli e villaggi. La sera aloggiamo a Vuinter ${ }^{151}$ per due leghe $1 / 2$, che è un villaggio seguendo il Reno co le vigne e villaggi spessi: qui ci fu detto che 4 leghe di là dal Reno vi è lo stato del Conte di Siena [sic] assai ricco, li antichi del quale dicano essere venuti di verso Roma, e l'arme sua essere un leone, ma non seppeno il colore. La mattina seguente seguendo il Reno, ma con li monti un poco più alti, ma bene con vigne e castelli a piedi e villaggi per tre leghe trovamo Anforse darnosch ${ }^{152}$, castello grande, e a 6 Confluentia153 o vero Convalentia // [208r] terra grande dove alle mura passa la Mosella sotto ponte di 15 archi e entra nel Reno, dove desinamo; la sera seguendo pure il Reno con le vigne e villaggi alloggiamo a Pobous [sic] castello per tre leghe, ma più longhe, trarando ${ }^{154}$ [sic] il medesimo viaggio.

La mattina seguente desinamo a Vuissel [sic] castello per tre leghe, ma a 2 havevamo trovato Lanthgauu [sic] pure castello; la sera allogiamo a Pignel castello per tre leghe, dove anche desinamo la mattina seguente. Da un lato vi passa il Reno e da piedi il fiume Dencho ${ }^{155}$ [sic] che entra nel Reno e lo fa peninsula, sotto ponte di 12 archi; il castello è assai grande e bello. La sera alloggiamo a Magontia ${ }^{156}$ per 4 leghe, ma il camino non facemo longo il Reno per abbreviarlo, che ben vi seguono li villaggi e castella e vigne, anco che non tante come prima havevamo trovate, e li monti sono più alti. Dentro a la porta di Magontia ne la strada e nel mezo vi sono fitte tre pietre grandi, dove è scritto ebraico. La città ha arcivescovado et è uno delli elettori dell'imperio. È assai grande ma non troppo bella: la chiesa maggiore è assai bella et ha due cori, uno da capo et uno da piedi. Sonovi più anticaglie di sepolcri, fra li altri fuori della città poco, a s. Albano convento di frati, in un orto vi è una piramide, ma assai guasta, dicano essere il sepolcro di Druso e la piramide è murata ma è cosa durissima: il Rheno

150 Bonn.

151 Königswinter.

152 Andermach?

153 Koblenz.

154 “trando", Fumi/Lisini, Genealogia, p. 129b.

156 Mainz. 
[sic] passa accanto alla città. Il giorno partimo et alloggiamo a Opem ${ }^{157}$ castello sul Reno per 3 leghe: facemo il camino lontano dal Reno, e trovamo // [208v] vigne assai, benché non tante come da prima. La mattina seguente desinamo a Vormes overo Vormatia ${ }^{158}$ per 4 leghe, dove anche alloggiamo. La città è minore di Magontia e più brutta, assai povera, sono quasi tutti luterani, in particolare il Rheno vi passa lontano un archibusata [sic]. La mattina seguente desinamo a Auchresem ${ }^{159}$ [sic] villaggio per 3 leghe, lontano un poco dal Rheno: il paese è bello e buono, se bene ha vicini li monti. La sera alloggiamo a Spira ${ }^{160}$ per 3 leghe: la città è assai grande né troppo bella, se bene vi sono assai case murate; vi è la camera imperiale. Ne li chiostri de la chiesa grande vi è fatto di pietra l'orto dove nostro Signore fece oratione, sonovi li giudei che lo pigliano e li apostoli di statura comune: cosa assai bella. Nella piazza della detta chiesa da mano sinistra in una faccia d'una casa vi è dipenta l'arme de Piccolomini col cappello e la croce sopra, come arcivescovo. Li uomini sono quasi tutti lutherani. Il Reno li passa lontano $1 / 2$ leghe. Havemo in Sphira [sic] audientia da Sua Maestà, e ci licentiamo. A dì 26 Giugno in giovedì ale 6 hore dopo mezo dì ci fermamo in Spira 6 giorni; il 7 [sic] a dì 28 in sabato partimo, che il dì avanti era partita Sua Maestà per $1 / 2$ lega; passamo il Reno in barca, a 3 leghe trovamo Prisel ${ }^{161}$ [sic] castello, ove era sospetto di peste a 5 trovamo Pretti 162 castello del conte Palatino elettore, ove desinamo et alloggiamo. Le leghe sono misura 5 l'una; la mattina seguente desinamo a Faighen castello per 2 leghe di 6 miglia l'una. // [209r] La terra è assai grande e bella del ducato di Virtembergh, paese bellissimo con colline domestiche e salvatiche e buon terreno. Partimo il giorno et a una legha trovamo Scurber ${ }^{163}$ [sic] Tinghen castelletto, e a 3 Canstat ${ }^{164}$ castello pure di Virttimbergh dove alloggiamo e bene. Il paese seguitò bellissimo e con vigne assai. La mattina seguente a una lega trovamo Uslingh ${ }^{165}$ castello grande, bello e forte per le mura, rivellino e fossi e acqua: vigne trovamo senza qualità continuamente, e per avanti vedevamo per piano e per poggi; a

\footnotetext{
157 Oppenheim.

158 Worms.

159 Mannheim?

160 Speyer.

161 Perhaps "Prutel"; "Pnuel", Fumi/Lisini, Genealogia, p. 130a.

162 Ispringen?

163 "Schurber" Fumi/Lisini, Genealogia, p. 130a.

164 Stuttgart.

165 Esslinger am Neckar.
} 
3 trovamo Ghepinghen ${ }^{166}$ villaggio pure di Virtembergh, ma manco vigne, dove alloggiamo. La mattina seguente, che fu il primo di Luglio, desinamo a Gheslinghen per tre leghe longhissime, castello assai grande e bello e forte per le mura, rivellini e fossi con acqua: non trovamo più vigne; la sera caminando per poggi assai grandi alloggiamo in Ulma ${ }^{167}$ per tre leghe longhissime, dove per una legha [sic] appresso a Ulma ci raggionse Monsignore d'Aras, al quale tenemo compagnia fino al suo alloggiamento dentro Ulma, quale è posta in piano e da la banda che entramo è sopraffatta da poggi, dall'altra poi, che uscimo, passa alle mura il Danubio e sotto ponte, e non è molto grosso non vedemo barche. La città non è molto grande, è assai bella per belle // [209v] strade e belle case che sono dipente: assai sono di legname. La chiesa grande e assai bella col suo campanile: l'immagini sonovi levate, se bene ve ne sono state ritornate a 4 altari; le donne vi sono assai belle. L'arme della città è la balzana, ma il negro è di sopra.

La città è forte per le mura, rivellini, fossi con acqua e baluardi: dopo desinare partimo il giorno seguente intrata Sua Maestà sur [sic] una chineetta baia coll'archibusetto all'arcione, e indosso una vestetta negra di velluto sciolta, messe le maniche, un cappelletto di taffetà in testa. Alloggiamo a Ghenspurgh ${ }^{168}$ castelletto per leghe 2 longhissime. La mattina seguente desinamo a Zomeruis ${ }^{169}$ villaggio del cardinale d'Augusta per leghe 4 minori, dove anco alloggiamo: il viaggio fu per colline. La mattina seguente a li 4 di luglio in venardì arrivamo a desinare a Augusta Vindelica ${ }^{170}$ per leghe tre di miglia quattro l'una, il camino fu per poggi non troppo alti assai boscati, dove sono pini assai. Sua Maestà entrò in Augusta a li 8 di Luglio al tardi nel mede[si]mo habito che entrò in Ulma, con suo archibusetto all'arcione della chinea ${ }^{171}$, et a man sinistra era il Re de Romani ${ }^{172}$, quale era venuto due giorni avanti, dinanzi a Sua Maestà era il prencipe suo figlio ${ }^{173}$ a man destra, et a la sinistra il re di Veles ${ }^{174}$ moro, e dopo Sua Maestà era a

166 Geislingen an der Steige.

167 Ulm.

168 Gunzburg?

169 Zusmarschausen?

170 Augsburg?

171 A small meek horse.

171 A small meek horse.

172 Ferdinand I von Habsburg, Holy Roman Emperor (1503-1564).

173 Philip II of Spain.

174 Possibly the town of Veles in Macedonia. 
man destra il cardinale di Augusta ${ }^{175}$ et a la sinistra il Duca d'Alva ${ }^{176}$. Visitamo // [210r] il Re de Romani, Monsignor di Granvela et il cardinale d'Augusta e dali medesimi tollemo licentia e da Sua Altezza e da monsignor d'Aras. Augusta è posta in piano, nondimeno vi è dentro un poco di salita a la porta, d'onde [sic] entramo. Passa il fiume ... [sic] non molto grosso; dall'altra parte della città passa il fiume Lichio ${ }^{177}$ assai grosso. La città è assai grande e bella, massime per 3 o 4 strade che vi sono e per li edifitii, che quasi tutti sono murati e dipenti di fuora; passano per la città canali. Sono nella città due torroni, dove sono magisteri et edifitii che dell'acqua che hanno nel fondo ne tirano in cima, e di poi per canali si distribuisce per tutta la città: cosa molto bella artifitiosa e notabile, delli quali uno dicano [sic] essere costo $\mathrm{x}^{\mathrm{m}}$ fiorini d'oro, che il fiorino è 15 bazi. Vi sono mercanti assai ricchi, che vi sono li Fuccari178 [sic], fannovisi i fustagni dicano per 50000 scudi l'anno; artefici sonovi assai, massime di ferramenti, archibusi, horologii e studioli, e buonissimi maestri; giardini sonovi bellissimi per artifitii d'acqua, e copia di frutti; sonovi certe case a modo di castello, che sono de Fuccari, che le tengano per li poveri. Le donne in Augusta generalmente sono belle: sono quasi tutti lutherani; la chiesa grande non è troppo bella e vi sono le immagini. // [210v]

La città si fortifica, che vi si rifanno le mura e i fossi. Le monete sono come in Colonia, però il fiorino lo fanno di bazi 15; l'arme di Augusta è una listra [sic] verde in scudo mezzo rosso, che è da mano destra, e mezo braccio da la sinistra. Fermamo in Augusta diciannove giorni: alli 22 Luglio doppo desinare partimo; alloggiamo a Landoperg ${ }^{179}$ castello del Duca di Baviera è assai grande per sei leghe assai piccole caminando longo il fiume Lichio $^{180}$, che li passa a la porta. La mattina seguente fumo a desinare a Seivuaghen ${ }^{181}$ castello assai grande del Duca di Baviera, per 5 leghe un poco maggiori vi passa il fiume Lichio, e ci alloggiamo ancora per havere male il mio cavallo Chiappino. Non vi si brucia legne, se non di pino, che ve ne sono le selve, e quasi tutte le case sono di travicelli di pino l'uno sopra l'altro. La mattina seguente, lontano mezza lega, si morì il cavallo mio

175 Otto Truchsess von Waldburg (1514-1573), Cardinal-Bishop of Augsburg.

176 Fernando Álvarez de Toledo y Pimentel, 3 ${ }^{\text {rd }}$ Duke of Alba (1507-1582).

177 Lech.

178 Függer.

179 Landsberg am Lech.

180 Lech River.

181 “Schivvagen” Fumi/Lisini, Genealogia, p. 130b. Perhaps Schongau. 
detto nel mezzo della strada, penso di dolori; e caminando per montagne di pini et abeti desinamo a Hamberg 182 villa per quattro leghe grandi, dove anche allogiamo per la pioggia. La mattina seguente // [211r] desinammo a Porichich ${ }^{183}$, villa per leghe tre, e le due ultime furno per una valle assai profonda, fra le montagne coperte di neve, e abeti. A allogio fumo a Mitevald $^{184}[\mathrm{sic}]$ villa per tre leghe, caminando pure per la valle al medesimo modo, e mangiamo della neve.

Le case vi sono pure di travicelli. La mattina seguente seguendo il camino con freddo per la valle fra le montagne lungo un fiume per tre leghe desinamo a Seveld ${ }^{185}$ villaggio dove è il miracolo dell'Eucaristia et è quello che sprofondò all'altare, e quivi desinamo con monsignore Pighino nuntio apostolico ${ }^{186}$, che andava a Sua Maestà; a 2 leghe poi trovamo Rirene $^{187}$ [sic] villaggio e a tre Ispruc ${ }^{188}$ castello piccolo, ma molto bello per li edifitii dipinti, e li passa alle mura un fiume assai grosso, e sotto un ponte di legname. Vi è il palazzo del Re de Romani, che la terra è sua per essere nel Tirolo, dove alloggiamo. Ispruc è posto pure fra le montagne, ne le quali si vedeva la neve. La mattina seguente desinamo per tre leghe a Damot, villaggio assai grande posto pure nella medesima valle fra le montagne, e ci alloggiamo ancora. La mattina a una lega $1 / 2$ ne la strada trovamo in una colonna un epitaffio dove è scolpito di bronzo Sua Maestà el serenissimo Re de Romani // [211v] che s'abbracciano.

A tre leghe poi trovamo Sterzing ${ }^{189}$ castello, dove era sospetto di peste, e a 7 caminando pure per la valle al medesimo modo, e d'onde [sic] uscivano acque assai, che facevano fiume a Prieu ${ }^{190}$ overo Prissinon, castello piccolo e bello, che vi passa il fiume accanto per essere pure ne la valle, dove desinamo e alloggiamo, e cominciamo a trovare de le vigne. La mattina seguente, continuando il viaggio pure fra le montagne e ne la valle, a 2 leghe trovamo La Chiusa ${ }^{191}$ castelo [sic], e a tre Colman villaggio, dove

\footnotetext{
182 Oberhammergau?

183 Garmisch-Partenkirchen?

184 Mittenwald.

185 Seefeld in Tirol?

186 Sebastiano Antonio Pighino (1500-1553).

187 Reith bei Seefeld?

188 Innsbruck.

189 Vipiteno.

190 “Priea” Fumi/Lisini, Genealogia, p. 131a.

191 Klausen.
} 
desinamo; e di poi, seguendo pure fra le montagne per la valle, alloggiamo a Pulsan castello grande e assai bello per tre leghe, dove passa il fiume. La mattina seguente continuando il viaggio pur per la valle, fra le montagne altissime vestite d'abeti pure e di pini, desinamo a Nojamar ${ }^{192}$ [sic] che è villaggio grande per tre leghe et per le due ultime venimo lungo il fiume Adice $^{193}$ a alloggio, seguendo pure lungo l'Adice per la valle fra le montagne fumo a san Michele villaggio per due leghe. La mattina seguente lontano una legha [sic] saglimo forse un miglio, e lassando un poco l'Adice a mano destra seguendolo un poco di lontano, desinamo a Trento città per leghe due, dove // [212r] dove accanto vi passa il fiume Adice. La città è posta a piedi le montagne et è assai piccola, ma assai bella e fa confino tra Alemagna et Italia. È del vescovo di Trento, vi è castello dove è bel palazzo del Vescovo. La chiesa grande non è molto bella, in un altra [sic] chiesa nuova vi è un bellissimo organo per il finimento di pietra, e bonissimo al suono; vi è il filatoio, dove lavorava la seta cosa bella. Sonovi parecchi palazzi; fuore d'una porta vi è un bel ponte di legname sopra l'Adice; vi è una sola strada che servi lingua e costumi tedeschi, ove sono l'hostarie della Rosa e del Pesce: ci alloggiamo la sera ancora. La mattina seguente il primo d'Agosto, seguendo pure fra montagne e lungo l'Adice, desinamo a Rovereghe ${ }^{194}$ per miglia quindici, che non si parla più per leghe, e quivi ritrovamo il suono dell'ore al modo nostro d'Italia, e quivi desinamo. Di poi seguendo pure fra le montagne per la valle lungo l'Adice, a 10 miglia trovamo Hala ${ }^{195}$ villa, e a 15 il Borghetto villetta, dove alloggiamo. La mattina seguente pure fra le montagne e lungo l'Adice a 10 miglia trovamo la chiesa de Venetia, che è passo fortissimo per essere da un lato la ripa dell'Adice altissima, e dall'altro la montagna tutta di sasso senza saglita, e la // [212v] strada, che scende per due tiri di mano tutta di un sasso, dove poi è una porta con un torrone: e quivi i Venetiani tengano la guardia. A 12 miglia trovamo Volerne villa, dove desinamo, e vi veddemo un bel palazzo, ma a due miglia havevamo trovato il confino de Venetiani col Tirolo; seguendo poi fra le montagne alte lungo l'Adice per miglia quattro, e di poi trovando montagne piccole dal lato sinistro, e dal destro seguendo l'Adice fumo alloggio a Verona, città de Venetiani per miglia 15. Verona è città grande ma non troppo piena: vedemovi un arco antico con due porti; vi è un colosseo rotondo di fuore, ma dentro ovato più piccolo di quello di

\footnotetext{
192 Egna, Neumarkt?

193 Adige.

194 Rovereto.

195 Ala.
} 
Roma, ma più integro; per la città passa l'Adice sotto ponti bellissimi, vi è il castello e la città è forte. La mattina seguente andando per piano vedendo colline desinamo a Villa Franca ${ }^{196}$, oggi villa di 500 fuochi già castello per 10 miglia; di poi seguendo a sei miglia trovamo il confino col Mantovano, a 8 trovamo Castiglione castello, a 14 Mantova, dove alloggiamo. La città è posta in piano circondata tutta d'acque come paludi per l'acqua del lago di Garda e del fiume Mincio, e così è fortissima; per la città passa un canale assai grande. La città è // [213r] è mercantile assai, vi si lavora di lavori d'agodie [sic] infinitamente; giudei vi sono assai; li edifitii vi sono belli che dentro e di fuore sono dipinti. La mattina seguente ci desinamo, di poi seguendo il camino a 10 miglia trovamo la posta di Correggio, dove passamo il Po in barca; a 12 san Benedetto villa, dove alloggiammo. Quivi è il monastero principale de monaci negri, che da' il nome alla villa, quale è bellissima per il convento e più per la chiesa: vi vedemo in sepoltura l'effigie di papa Pio secondo del [canc: 1549] 1459. Vi è un bellissimo artifitio di condurre l'acqua d'un pozzo in cima d'una stanza, d'onde [sic] poi si distribuisce per tutto il monastero. La mattina seguente a miglia sette trovamo Mondanello ${ }^{197}$ [sic] villa dove passamo il fiume Sechia in barca; a 8 il confino fra il Mantovano e la Mirandola, a 10 la Concordia villa, dove già era fortezza, e quivi desinamo: ci è la posta, e a 5 miglia si vede di 4 la Mirandola. Di poi seguendo a due miglia il confino con Bologna, a tre s. Presidonio [sic] villa, a 10 seguendo il fiume Sechia san Martino, dove è la posta sola, e quivi alloggiamo. La mattina seguente a tre miglia la Pioppa villetta, a 7 buon // [213v] Porto, dove passamo il fiume Panara [sic] e si paga il passo; a 13 la Crocetta villetta dove è la posta, a 16 san Giovanni ${ }^{198}$ castello assai grande, dove desinamo. A alloggio la sera in Bologna per miglia dodici dove anche desinamo. La mattina seguente di poi a 8 miglia Pianoro, e cominciando a salire le montagne a 16 Lojano $^{199}$, dove alloggiamo. La mattina seguente a miglia sette Scarcalasino villa, a 14 Fiorenzuola ${ }^{200}$ castello assai grande e bello; a 19 saglimo al giogo sommità de la montagna di poi scendendo a 24 la Scarparia ${ }^{201}$, ove desinamo. Quivi fanno infiniti coltelli e forbici; seguendo

\footnotetext{
196 Villafranca di Verona.

197 Corrected on the previous word.

198 San Giovanni in Persiceto.

199 Loiano.

200 Firenzuola.

201 Scarperia.
} 
di poi a 2 miglia il ponte Sieve202 che piglia il nome per il fiume che vi passa, villa assai buona. A 9 l'Ucellatoio villetta, a 14 Firenze, dove alloggiamo. La mattina seguente a desinare a san Casciano castello per miglia otto, di poi a miglia sette le Tavernelle ${ }^{203}$ villa. A 9 Barbarino ${ }^{204}$ castelletto, a 12 Poggibonzi ${ }^{205}$ castello assai grande, dove alloggiamo. La notte a sei hore ci partimo, a tre miglia trovamo Staggia castelletto dove passa il fiume, a 6 Monteriggioni, a $12 \mathrm{col}$ nome di Dio al levare del sole ar // [214r] arrivamo a la posta di Siena, che fu a dì 10 Agosto il dì di san Lorenzo 1550 .

Copiato il sopradetto itinerario di $\mathrm{m}$. Lelio Pecci dal suo proprio originale esistente appresso gl'eredi del già signor Francesco Piccolomini.

\section{Works CiTED}

\section{Manuscript Sources}

Siena. Archivio di Stato di Siena. (ASS)

Balìa $169,179,719,720,722$

Siena. Biblioteca Comunale degli Intronati (BCS)

MS C.IV.24, fols. 195v-214r, "Itinerario di Lelio Pecci dottore in Fiandra, oratore a Carlo Quinto imperatore 1549 155.”[sic]

\section{Printed Sources}

Fumi, Luigi and Alessandro Lisini. Genealogia dei conti Pecci signori di Argiano. Pisa: R. Litogr. Gozani / Rocca S. Casciano, Tipogr. Cappelli, 1880.

\section{Electronic Sources}

Dizionario etimologico online. www.etimo.it

\footnotetext{
202 Pontassieve.

203 Tavarnelle Valdipesa.

204 Barberino Valdipesa.

205 Poggibonsi.
} 